\title{
Human coronaviruses and therapeutic drug discovery
}

\author{
Lan-Gui Song ${ }^{1 *+}$, Qing-Xing Xie ${ }^{2+}$, Hui-Lin Lao ${ }^{2+}$ and Zhi-Yue Lv ${ }^{2,3,4^{*}}$
}

\begin{abstract}
Background: Coronaviruses (CoVs) are distributed worldwide and have various susceptible hosts; CoVs infecting humans are called human coronaviruses (HCoVs). Although HCoV-specific drugs are still lacking, many potent targets for drug discovery are being explored, and many vigorously designed clinical trials are being carried out in an orderly manner. The aim of this review was to gain a comprehensive understanding of the current status of drug development against HCoVs, particularly severe acute respiratory syndrome coronavirus 2 (SARS-CoV-2).

Main text: A scoping review was conducted by electronically searching research studies, reviews, and clinical trials in PubMed and the CNKI. Studies on HCoVs and therapeutic drug discovery published between January 2000 and October 2020 and in English or Chinese were included, and the information was summarized. Of the 3248 studies identified, 159 publication were finally included. Advances in drug development against HCoV, especially SARS-CoV-2, are summarized under three categories: antiviral drugs aimed at inhibiting the HCoV proliferation process, drugs acting on the host's immune system, and drugs derived from plants with potent activity. Furthermore, clinical trials of drugs targeting SARS-COV-2 are summarized.

Conclusions: During the spread of COVID-19 outbreak, great efforts have been made in therapeutic drug discovery against the virus, although the pharmacological effects and adverse reactions of some drugs under study are still unclear. However, well-designed high-quality studies are needed to further study the effectiveness and safety of these potential drugs so as to provide valid recommendations for better control of the COVID-19 pandemic.
\end{abstract}

Keywords: Human coronavirus, Drug discovery, Drug development, SARS-CoV-2

\section{Background}

Coronaviruses (CoVs), which consist of nucleoproteins $(\mathrm{N})$, envelope proteins $(\mathrm{E})$, matrix proteins $(\mathrm{M})$, spike proteins $(\mathrm{S})$, and many non-structural proteins, are linear single-stranded RNA viruses [1]. CoVs are a large family of viruses with various susceptible hosts, including humans and many other animal species, such as camels, cattle, cats, and bats [2]; those infecting humans are called

\footnotetext{
*Correspondence: songlg5@mail.sysu.edu.cn; Ivzhiyue@mail.sysu.edu.cn ${ }^{\dagger}$ Lan-Gui Song, Qing-Xing Xie and Hui-Lin Lao contributed equally to this work

${ }^{1}$ The Eighth Affiliated Hospital, Sun Yat-Sen University, Shenzhen, Guangdong, China

${ }^{2}$ Zhongshan School of Medicine, Sun Yat-Sen University, Guangzhou, Guangdong, China

Full list of author information is available at the end of the article
}

human coronaviruses (HCoVs). $\mathrm{HCoVs}$ include $\mathrm{HCoV}$ 229E, NL63, OC43, HKU1, severe acute respiratory syndrome coronavirus (SARS-CoV), Middle East respiratory syndrome coronavirus (MERS-CoV) and SARS-CoV-2 and are recognized to be important causes of respiratory tract infection [3, 4]. The former four types are considered common HCoVs and usually lead to mild to moderate upper respiratory tract illnesses [4], while the other three types are different. After the outbreaks of SARS in 2002 and MERS in 2012, the world experienced the coronavirus disease 2019 (COVID-19) pandemic caused by SARS-CoV-2 in 2020. Similar to SARS-CoV, SARS-CoV-2 appeared unexpectedly and spread throughout the world rapidly, with 56623643 confirmed cases and 1355963 deaths [5]. Fever and cough are the most common 
symptoms of COVID-19; patients infected with SARSCoV-2 can develop dyspnoea a week after onset, and critical patients usually die from uncontrollable sepsis, respiratory failure, acute respiratory distress syndrome (ARDS) and septic shock [6]. Therapeutic interventions excluding virus-specific drugs, are often experiential or anecdotal and have not been tested in an integrated trial to provide sufficient and widely accepted evidence. The most common interventions include a combination of antivirals (such as ribavirin and lopinavir/ritonavir) and interferons (IFNs), corticosteroids, COVID-19 convalescent plasma and supportive treatment for critical patients [7].

Previous studies have revealed the invasion mechanism of HCoVs. In brief, S1 binds to the relevant receptor and induces endocytosis, then the conformation of the S2 subunit changes. The viral envelope fuses with the endosomal membrane and releases the nucleocapsid or viral genome [8]. Genomic RNA (gRNA) serves as a translation template for polyproteins pp1a and pp1ab, which are automatically hydrolysed into various non-structural proteins (NSPs), such as papain-like protease (PLpro), 3C-like protease (Mpro), and RNA-dependent RNA polymerase (RdRp). Full-length gRNA is replicated by negative sense intermediates and transcribed into subgenomic RNA (sgRNA). sgRNA encodes the structural proteins of the virus $(\mathrm{N}, \mathrm{M}, \mathrm{E}$, and $\mathrm{S})$ as well as helper proteins (e.g., 3, 4a, 4B, 5, and 8b). Particle assembly occurs in the ER-Golgi intermediate compartment (ERGIC) and is then released in the vesicle via the secretory pathway [3]. Interruption of the proliferation process might help cure patients and disrupt transmission. As the understanding of both the biological characteristics and pathogenicity of HCoVs has deepened, many potent targets for drug discovery have been explored, such as inhibiting $\mathrm{HCoV}$ invasion and strengthening host immune defences. In addition, traditional Chinese medicine might be effective in the fight against HCoVs. To establish additional evidence supporting recommended treatment strategies, some drugs, such as remdesivir, favipiravir, lopinavir/ ritonavir, arbidol/umifenovir, and hydroxychloroquine, have been tested in vigorously designed clinical trials. Herein, we review the progress in therapeutic drug discovery and development, including drugs that inhibit the $\mathrm{CoV}$ proliferation process (attachment and entry, replicase expression, replication, transcription and translation, assembly and release), antiviral drugs that affect the action of the host's immune system, and drugs derived from plants with potent activity, in order to accelerate drug discovery and development, especially during the current pandemic.

\section{Main text \\ Methodology \\ Search strategy}

We searched two databases: PubMed (https://www.ncbi. nlm.nih.gov/pubmed/) and CNKI (www.cnki.net). We searched for coronavirus (or $\mathrm{HCoV}$ ) and important components (such as S protein, PLpro, Mpro, NSPs, RNA, N protein, E protein, host factors) and drugs (or Chinese medicine, plant derivates, or research or treatment). References of studies retrieved were cross checked as well. All the search results were evaluated. First, the titles and abstracts were screened to identify relevant studies; then, full texts were evaluated carefully to determine eligibility for inclusion. The complete search and selection processes were performed by two independent researchers. Any disagreements were resolved through consultation with a third researcher or team discussion until consensus was reached.

\section{Inclusion criteria}

(1) The target coronaviruses were $\mathrm{HCoVs}$, with special attention to highly pathogenic HCoVs; (2) The studied drugs included newly developed targeted drugs, broadspectrum antiviral drugs, small-molecule compounds, plant derivatives, etc.; (3) the research performed included in vivo or in vitro tests, clinical trials, or literature reviews; (4) the publication language was English or Chinese; (5) the literature type was an article, review, or clinical trial; and (6) the publication time was from January 1, 2000, to October 27, 2020.

\section{Exclusion criteria}

(1) Duplicate studies; (2) studies for which the full text was unavailable; (3) news, reports, interviews, comments, patents, letters, or case reports; and (4) reviews or studies with the aim of elucidating the impact of coronavirus infection on the underlying diseases and their treatment in a target population.

\section{Data extraction, summary, and analysis}

We classified the selected documents according to the following categories: (1) antiviral drugs intended to inhibit the $\mathrm{HCoV}$ proliferation process; (2) antiviral drugs that affect the action of the host's immune system; and (3) antiviral drugs derived from plants with potent activity. All articles were processed using NoteExpress V 3.0 (Beijing Aegean Technology Co., Ltd., Beijing, China).

\section{Results}

The scoping process

A total of 3248 records were retrieved. After excluding 322 duplicate records, 228 records with unavailable full texts, and 2539 records that met the exclusion criteria 
mentioned above, 159 records were finally included in this review. A flow diagram of the study selection process is shown in Fig. 1.

The proliferation process as well as the key targets of CoVs are presented (Fig. 2). A summary of the progress in therapeutic drug discovery and development targeting $\mathrm{HCoVs}$ is demonstrated below and is divided into three sections: drugs that inhibit $\mathrm{HCoV}$ proliferation (attachment and entry, replicase expression, replication, transcription and translation, assembly and release), antiviral drugs that affect the actions of the host's immune system, and drugs derived from plants with potent activity.

\section{Blocking the $\mathrm{HCoV}$ proliferation process is the key to identify effective drugs against the virus}

The drugs that target the $\mathrm{CoV}$ proliferation process are summarized in Table 1.

\section{Inhibition of attachment and entry}

The process of invasion can be divided into receptor binding and endocytosis [2]. Drugs developed from viruses or host structures that participate in the above two processes have the potential to block virus invasion.
Prevention of receptor binding The receptor binding domain (RBD) is the domain that binds to the receptor during $\mathrm{HCoV}$ invasion; RBDs have substantial diversity [2]. There have been many studies on therapeutic monoclonal antibodies (mAbs), including m336, m337 and m338, that target the RBD to prevent MERS-CoV invasion [9] and human-derived SARS-CoV [10, 11]. In addition to mAbs, receptor-derived proteins based on the ligand-binding domain, such as P4 and P5 peptides, can be utilized to competitively bind to the RBD [12].

To enter a cell, the RBD needs to bind to a receptor. Thus, in theory, drugs that compete with RBDs for receptor binding sites, such as $N$-(2-aminoethyl)-1-aziridineethanamine (NAAE) [13] and anti-dipeptidyl peptidase 4 (DPP4) mAbs, can block CoV invasion [14, 15]. However, considering that the receptors on the host cell surface also play an important role in the normal metabolism and function of the cell, the development of such drugs should take into account their impacts on the body, such as hypotensive and hypoglycaemic effects. Griffith$\sin$ (GRFT) can specifically bind to the glycosyl groups of protein $S$, thereby inhibiting virus invasion [16].

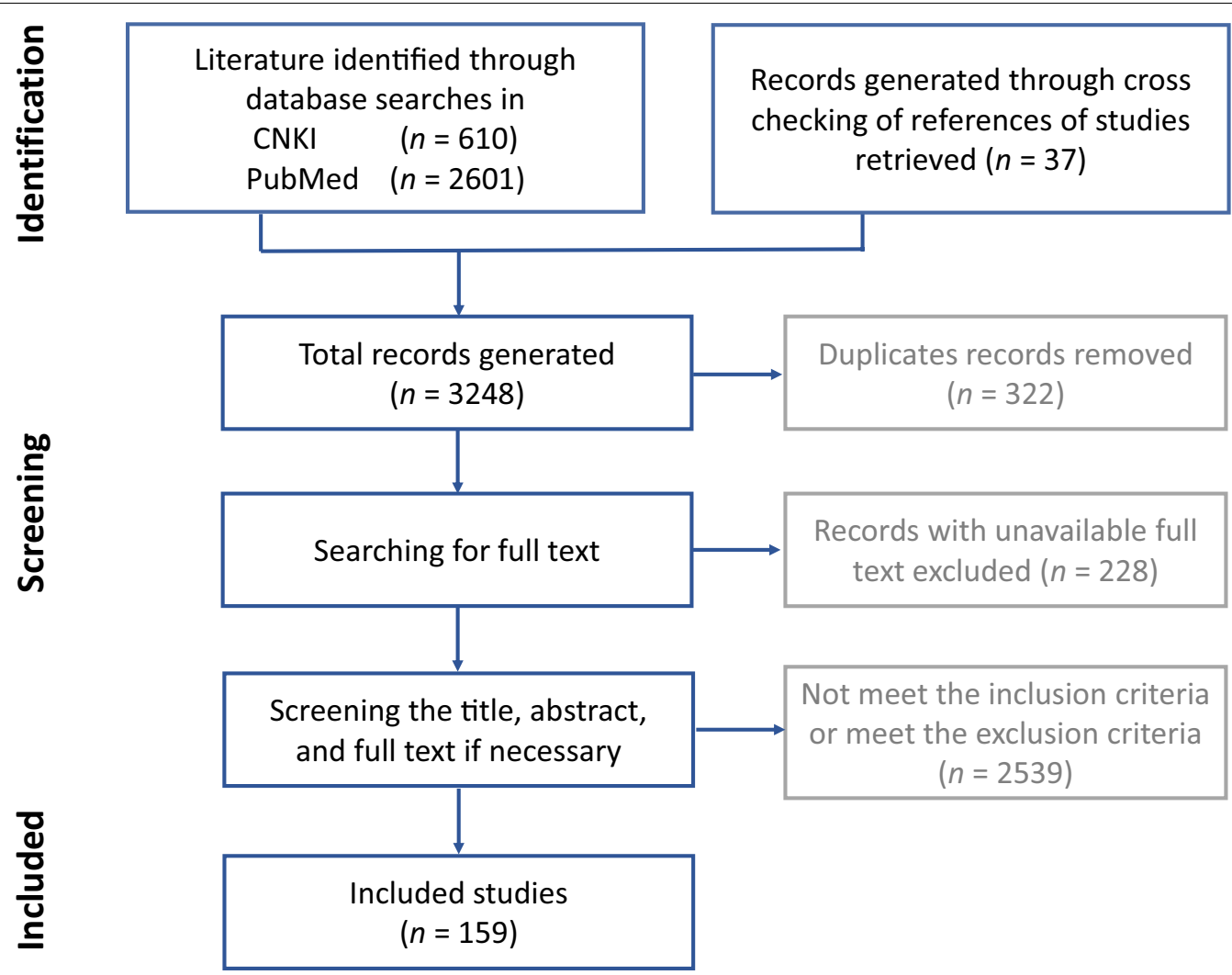

Fig. 1 PRISMA flow diagram of the scoping review process 


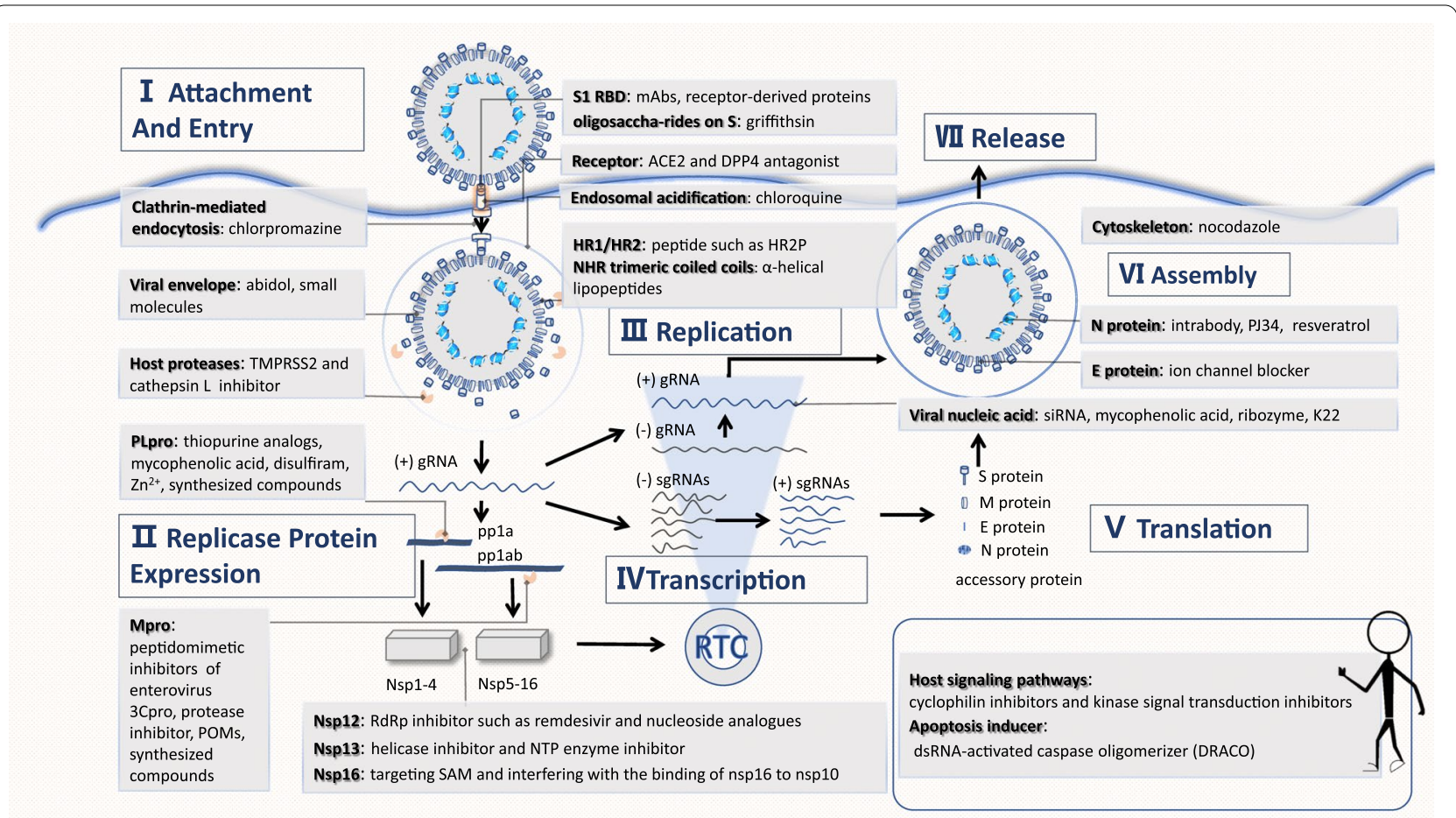

Fig. 2 The CoV proliferation process. TMPRSS2: Transmembrane protease serine 2; Zn²+: Zinc ion; PLpro: Papain-like protease; Mpro: 3C-like protease; 3Cpro: 3 C protease; POMs: Polyoxometalates; Nsps: non-structural proteins; NTP: Nucleoside triphosphate; SAM: S-adenosyl-L-methionine; RBD: Receptor binding domain; mAb: monoclonal antibodies; ACE2: Angiotensin converting enzyme 2; DPP4: dipeptidyl peptidase 4; HR1: Heptad repeat 1 domain; HR2: Heptad repeat 2 domain; gRNA: genomic RNA; sgRNA: subgenomic RNA; siRNA: small interfering RNA; NHR: N-terminal heptad repeat; dsRNA: Double-stranded RNA

Prevention of endocytosis Inhibitors of host proteases that cleave protein $\mathrm{S}$, such as transmembrane protease serine 2 (TMPRSS2) inhibitors (camostat [17], nafamostat [18]) and cathepsin L inhibitors (teicoplanin, dalbavancin), can prevent exposure and insertion of the hydrophobic end of S2 into the endosomal membrane [19]. Drugs targeting HR1/HR2, such as HR2P, P1 peptide, 229E-HR1P, 229E-HR2P and OC43-HR2P peptide [20-23], can prevent the formation of the 6-helix bundle structure, thereby inhibiting the fusion of the viral envelope with the endosomal membrane. Furthermore, arbidol [24], LJ001 [25], and NHR trimeric coiled coil alpha-helical lipopeptides prevent enveloped virus-cell membrane fusion [26]. Arbidol was tested in a clinical trial and appeared to reduce the SARS-CoV-2 RNA load [27]; however, other studies revealed that Arbidol did not improve the clinical outcomes of patients or SARSCoV-2 elimination $[28,29]$. Attention should be paid to host factors that affect endocytosis. For instance, chloroquine inhibits endosomal acidification [30,31], and chlorpromazine inhibits clathrin-mediated endocytosis [30]. Recently, chloroquine phosphate has been recommended by Chinese scholars for the treatment of SARS-CoV-2
[32], but some studies have shown that hydroxychloroquine induces cardiotoxicity [33, 34].

\section{Inhibition of replicase expression}

In the replication cycle, CoV RNA is first translated into two polyproteins, pp1a and pp1ab, which are then hydrolysed to generate sixteen NSPs with various functions [2]. Certain NSPs are essential for virus replication and transcription.

Papain-like protease (namely, NSP3 and PLpro) and Achilles' heel 3C-like protease (also known as NSP5 and Mpro) play a vital role in hydrolysing polyproteins to generate NSPs [2]. Hence, inhibitors of the two proteases can block the generation of NSPs.

PLpro Drugs targeting PLpro include the thiopurine analogues 6-mercaptopurine (6MP) and 6-thioguanine (6TG), mycophenolic acid [35], disulfiram [36], zinc ion $\left(\mathrm{Zn}^{2+}\right)$ and zinc conjugate inhibitors [37], as well as F2124-0890 [38].

Mpro Drugs targeting Mpro include peptidomimetic inhibitors of enterovirus 3Cpro (6b, 6c and 6d) [39], a novel series of fused 1,2,3-triazoles [40], lopinavir/rito- 


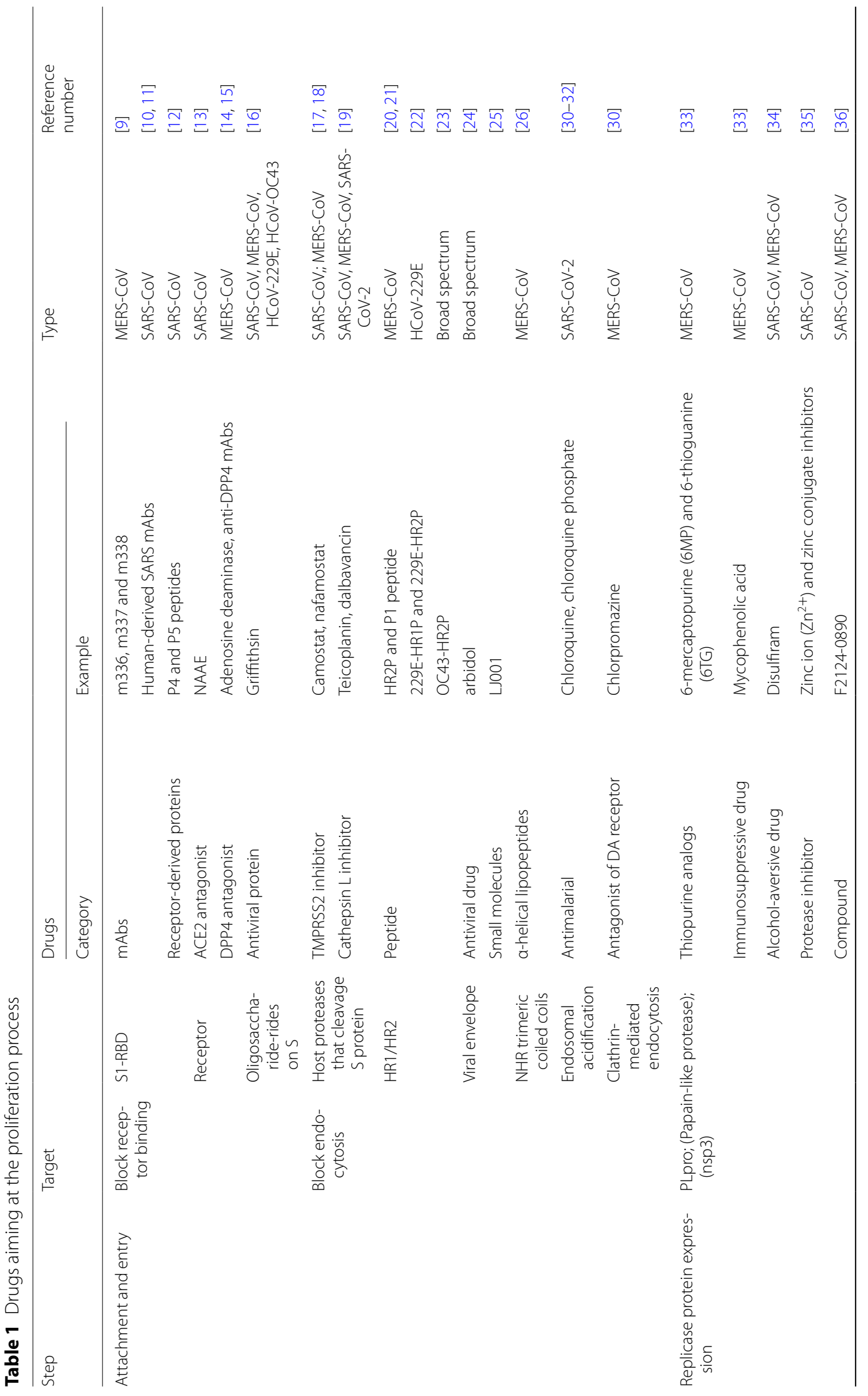




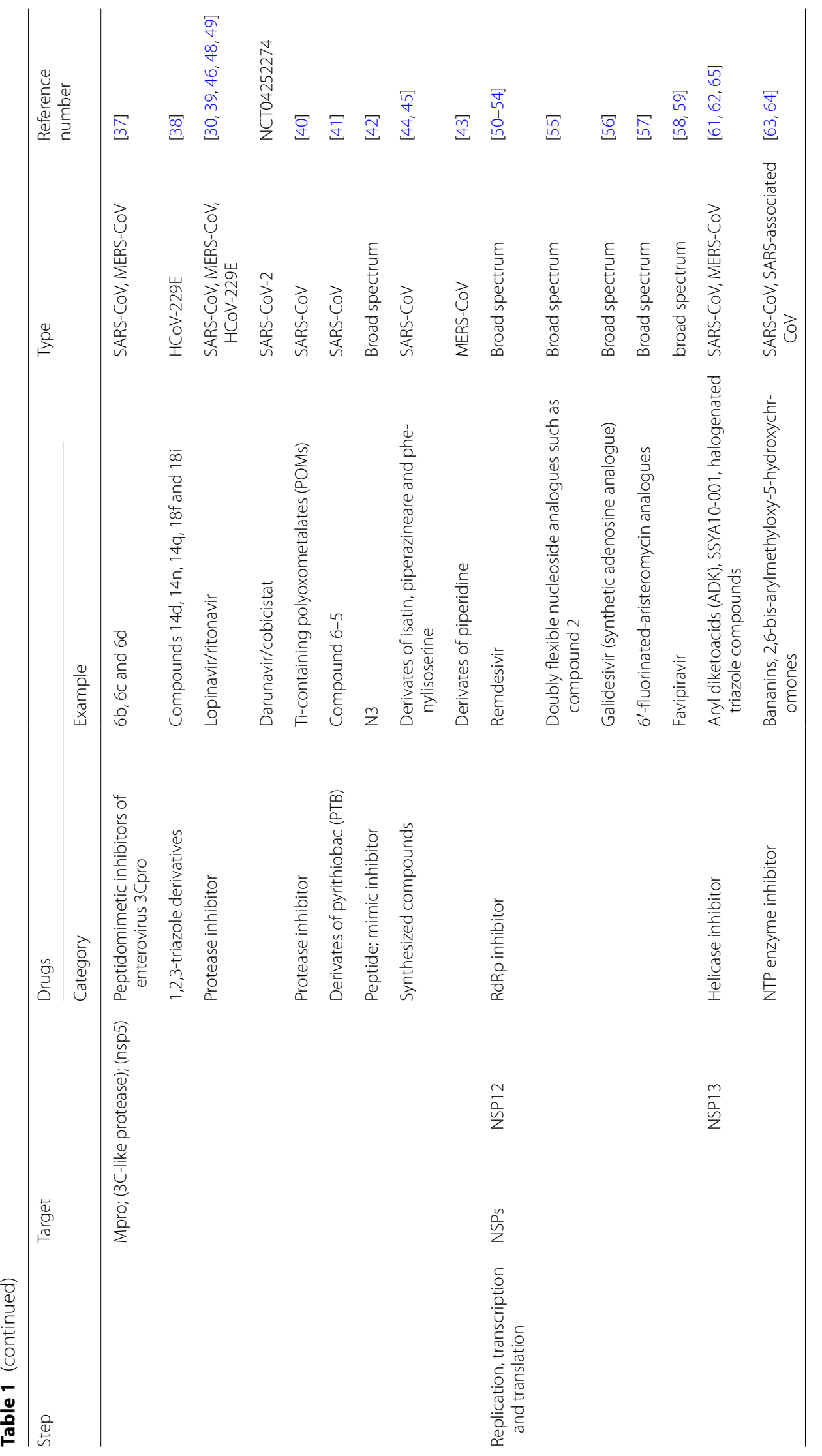




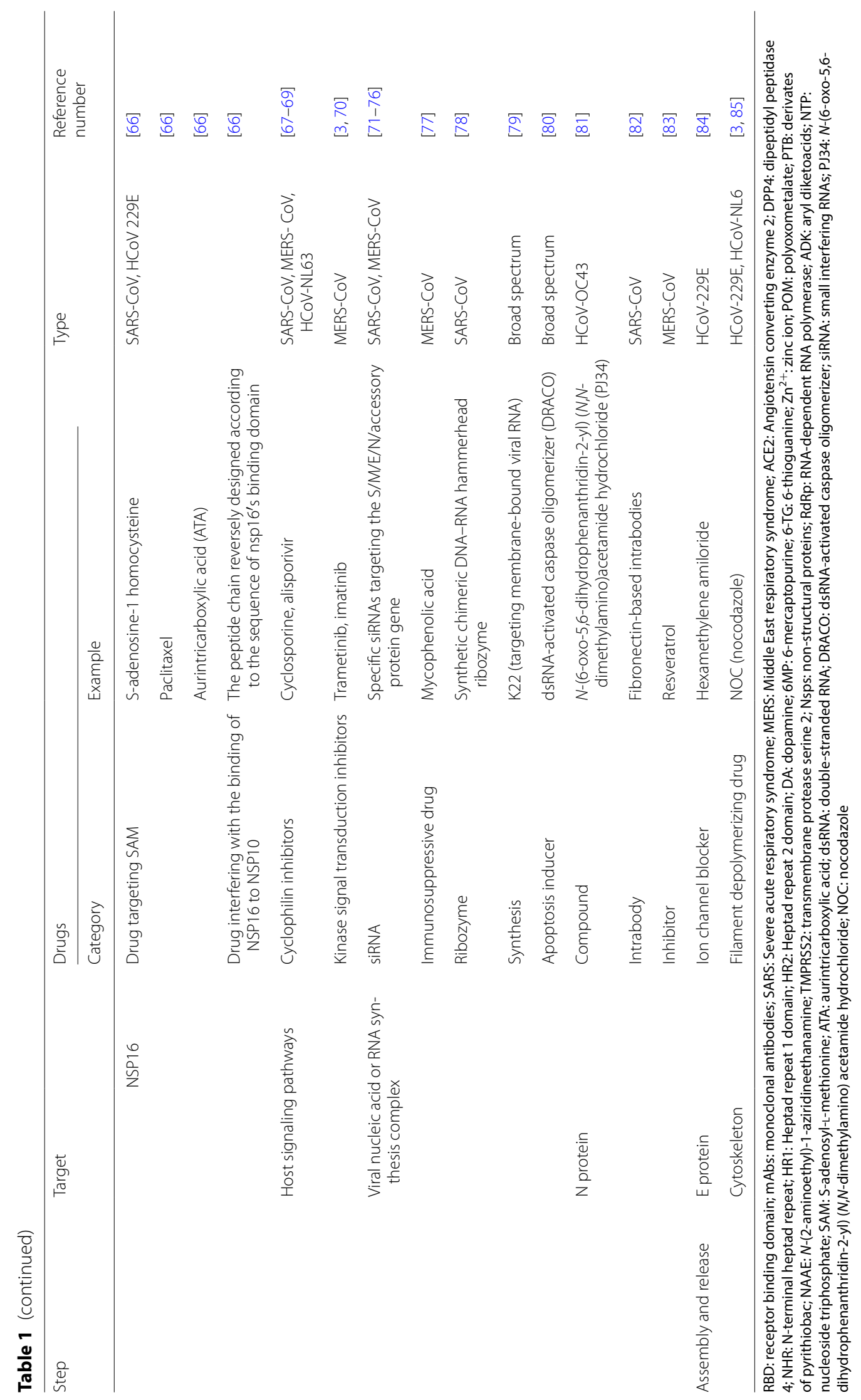


navir, [30, 41], Ti-containing polyoxometalates (POMs) [42], compounds $6-5$ derived from pyrithiobac (PTB) [43], some molecules such as N3 [44], and synthesized compounds (derived from isatin, piperazine, piperidine and phenylisoserine) [45-47]. According to a randomized control trial published in The Lancet, lopinavir-ritonavir was not associated with survival improvement or mortality reduction $[48,49]$, so the World Health Organization (WHO) terminated related experiments.

\section{Inhibition of replication, transcription and translation}

$\mathrm{CoV}$ replicase synthesizes the full-length antisense genome using gRNA as a template and then synthesizes new gRNA according to the sequence of the antisense RNA. Thereafter, with the help of RNA polymerase and certain transcription factors, the virus recognizes specific transcriptional regulatory sequences (TRSs) with "discontinuous transcription" and selectively transcribes all components that make up a mature mRNA. Finally, mRNA is translated into a variety of structural proteins (nucleocapsid protein N, membrane protein $\mathrm{M}$, envelope protein $\mathrm{E}$, and spike protein $\mathrm{S}$ ) and accessory proteins (such as 3, 4a, 4b, 5 and 8b) [2].

Essential NSPs A variety of NSPs play significant roles in the replication process, whereas drugs targeting them are limited.

NSP12 (RdRp inhibitors): The NSP12 (RdRp) inhibitor remdesivir prevents viral replication and thus reduces the viral load in patients [50]. However, two recent clinical trials have reached two different conclusions. A study published in the Lancet revealed that the drug is not effective [51-53], while a study published in New England Journal of Medicine showed that the drug shortened the length of hospitalization and virus removal time. However, this paper was withdrawn for many reasons [54]. Other drugs include a series of doubly flexible nucleoside analogues [55], galidesivir (BCX4430) [56], a novel synthetic adenosine analogue, 6 '-fluorinatedaristeromycin analogues [57], and favipiravir. Favipiravir has been associated with improvement in chest CT findings [58, 59]. However, the broad-spectrum antiviral drug ribavirin had no significant effects on clinical outcomes when administered alone for the treatment of SARS [60].

NSP13: With the activity of both nucleotide helicase and nucleoside triphosphate (NTP) enzymes, NSP13 functions to unravel the dsRNA helix. Drugs targeting NSP13 not only alter helicase activity [such as aryl diketoacids (ADK) and SSYA10-001] [61, 62], but also affect NTP enzyme activity [such as bananins and 2,6-bis-arylmethyloxy-5-hydroxychromones] [63, 64]. Furthermore, molecular docking results showed that 16 halogenated triazole compounds could bind to NSP13, with inhibitory effects [65].

NSP16 [S-adenosyl-L-methionine (SAM)-dependent 2'O-MTase]: Drug action mechanisms can be divided into two types: direct termination of $2^{\prime} \mathrm{O}$-MTase activity through the alteration of SAM (drugs that utilize this mechanism include S-adenosine-1 homocysteine, paclitaxel, and aurintricarboxylic acid (ATA) [66]) or alteration of $2^{\prime} \mathrm{O}-\mathrm{MTase}$ activity by interfering with the binding of NSP16 to NSP10 (drugs that utilize this mechanism include complementary reverse peptides designed according to the sequence of the NSP16 binding domain [66]).

Host signalling pathways Certain host signalling pathways are essential for viral replication [3]. The cyclophilin inhibitors cyclosporine and alisporivir regulate the interactions of cyclophilin with NSP1 and the calcineurin-NFAT pathway [67-69]. Kinase signal transduction inhibitors, such as trametinib and imatinib, block the ABL1, ERK-MAPK and PI3K-AKT-mTOR pathways, potentially preventing early virus invasion and resulting immune disorders [3, 70].

Viral nucleic acids and RNA synthesis complex Various small interfering RNAs (siRNAs) can interfere with viral replication as well as the expression of structural proteins and accessory proteins [71-76]. Mycophenolic acid may inhibit viral nucleic acid synthesis [77], but it is advisable to combine it with an interferon since its immunosuppressive effect may create an environment amenable to virus replication and dissemination. In addition, a synthetic chimaeric DNA-RNA hammerhead ribozyme can suppress the expression of SARS-CoV RNA [78]. Moreover, K22 can suppress RNA synthesis by inhibiting the formation of double membrane vesicles (DMVs) [79]. Finally, given the existence of replication intermediates, dsRNAactivated caspase oligomerizer (DRACO) can selectively induce apoptosis in cells containing viral dsRNA [80].

Protein $N$ Newly generated RNA needs to bind to protein $\mathrm{N}$ to form a nucleocapsid for stability; protein $\mathrm{N}$ also plays an important role in the normal replication and transcription of gRNA [2]. Therefore, drugs targeting protein $\mathrm{N}$, such as fibronectin-based intrabodies and the inhibitors PJ34 and resveratrol, may influence these processes [81-83].

\section{Inhibition of assembly and release}

Viral assembly occurs in the ERGIC, where proteins M and E play important roles [2]. Hexamethylene amiloride [84] blocks the $\mathrm{E}$ protein ion channel. $\mathrm{CoV}$ particles in 
ERGIC are transported through the secretory pathway in vesicles and released through exocytosis [2].

The interactions between the cytoskeleton and structural proteins are essential for the assembly and release of CoVs [3]. For example, nocodazole may reduce the amount of transmissible gastroenteritis virus (TGEV), which belongs to the genus $\alpha-\mathrm{CoV}$ and shares a similar assembly and release mechanisms with $\mathrm{HCoV}-229 \mathrm{E}$ and HCoV-NL63, particles released from the body [85]. Nonetheless, the advantages and disadvantages must be considered before administering the drug due to the significant role of the cytoskeleton in the normal metabolism and functioning of cells.

\section{Drugs that affect the action of the host's immune system could help relieve the symptoms Innate immunity}

Complement activation and IFNs are believed to play an active role in the innate immune response against $\mathrm{HCoVs}$.

Complement activation Inhibition of complement activation alleviates acute lung injury induced by SARS-CoV and MERS-CoV infection. For instance, anti-C5aR antibody treatment resulted in decreased viral replication in lung tissues in hDPP4-transgenic mice infected with MERS-CoV. SARS-CoV-infected $\mathrm{C}^{-/-}$mice exhibited significantly less weight loss and less respiratory dysfunction despite an equivalent viral load in the lungs [86-88].

IFNs. IFN- $\alpha / \beta$ (IFN-1) is an important component of innate immune defence, which protects mammalian hosts from viral infection [89]. While mild $\mathrm{HCoV}$ infections, such as infection by $\mathrm{HCoV}-229 \mathrm{E}$, typically induce a high level of IFN-I production [90], SARS-CoV and MERS-CoV were shown to suppress the activation of the host innate immune response by inhibiting interferon production or signalling. Several structural proteins (M and N) [91-93], NSPs (NSP1 and NSP3) [94-96], and accessory proteins of SARS-CoV and/or MERS-CoV were identified as IFN antagonists [92]. In addition to inhibiting $\mathrm{CoV}$ replication, drugs targeting these proteins may work by unblocking IFN suppression by the CoV. IFN has been clinically indicated to be effective for the treatment of SARS-CoV and MERS-CoV. In clinical treatment, the routine use of IFNs is not recommended for SARS-CoV treatment [97]. IFNs are usually administered in combination with other drugs, such as IFN- $\beta-1 b$ combined with lopinavir/ritonavir [98] or ribavirin and IFN- $\alpha$ combined with lopinavir/ritonavir [99], for MERS-CoV treatment. In severe to critical COVID-19 patients, early treatment with IFN- $\alpha 2 \mathrm{~b}$ can reduce in-hospital mortality, but it has no significant benefit in moderately ill patients [100].

\section{Cell-mediated immunity}

Lymphocytopenia is commonly observed in patients infected with SARS-CoV [97], MERS-CoV [101], or SARS-CoV-2 [102], but the mechanism remains unclear. Human $\mathrm{T}$ cells are highly susceptible to MERS-CoV infection. Studies have demonstrated that MERS-CoV persists in $\mathrm{T}$ cell-deficient mice but is cleared in B celldeficient mice, suggesting that $\mathrm{T}$ cells play a critical role in MERS-CoV clearance [103]. SARS-CoV-specific T cells also play important roles in the recognition and clearance of infected cells [104].

\section{Humoural immunity}

Antibodies play an important role in preventing $\mathrm{CoV}$ infection. Antibody production against protein $\mathrm{S}$ was less in SARS-CoV-infected patients with fatal outcomes than in non-severe patients [105]. The level and presence of antibodies are related to the clinical severity of SARS and MERS [106, 107]. Experiments have shown that antibody therapy improves symptoms and promotes recovery. SARS-CoV-specific monoclonal antibodies include human mAb CR3014 [10], CR3022 [108], and 5H10 [109]. MERS-CoV-specific monoclonal antibodies include m336 [110], REGN3051, REGN3048 [111], 3B11-N [112], LCA60 [113], MCA1 [114], MERS-4, MERS-27 [115], MERS-GD27, and MERS-GD33 [116]. Serum cross-reaction is important for both detection and treatment. Studies have shown the absence of cross-reactivity between SARS-CoV and MERS-CoV. The SARSCoV-specific human monoclonal antibody CR3022 can effectively bind to the RBD of SARS-CoV-2 [117].

\section{Convalescent plasma}

Convalescent plasma therapy may be beneficial for patients with early SARS infection because it provides antibodies from convalescent patients [118], but evidence of its efficacy in MERS-CoV patients is still lacking. It is recommended for the treatment of rapidly progressing, severe and critical cases of SARS-CoV-2 infection [99], but it is limited by safety concerns and inadequate sources. Trials indicate that convalescent plasma is most effective in reducing mortality when administered in the early stage of infection, but it does not significantly shorten the time to recovery $[119,120]$.

\section{Glucocorticoids}

Corticosteroids not only suppress lung inflammation but also inhibit immune responses and pathogen clearance. Available observational data suggest impaired clearance of SARS-CoV and MERS-CoV as well as increased complication rates in survivors receiving corticosteroid therapy. Therefore, it is not advisable to administer corticosteroid treatment in patients with 
SARS-CoV-2-associated lung injury or shock outside of a clinical trial setting [121]. Recent clinical trials suggest that early, low-dose methylprednisolone administered in the short term improved clinical outcomes and reduced mortality in severe COVID-19 patients [122124]. Guidelines from China recommend that glucocorticoids should be used in the short term as appropriate in patients with progressive deterioration of the oxygenation index, rapid radiographic development, and excessive activation of the inflammatory response [99].

\section{IL-6 receptor inhibitors}

IL-6 plays an important role in the development of a cytokine storm. As an IL-6 receptor inhibitor, tocilizumab does not prevent the disease from progressing, but it can reduce the symptoms of serious infection [125-127].

Clinical trials of drugs targeting SARS-CoV-2 are summarized in Table 2.

\section{Plant-derived Chinese medicine might have antiviral effect Single Chinese medicines and their associated active ingredients}

SARS-CoV-2 The traditional Chinese medicine components that might block the binding regions of grid3 and grid4 between angiotensin converting enzyme 2 (ACE2) and viral protein S include Folium mori, Atractylodes lancea, Fritillaria, Zingiber officinale, Lonicerae japonicae flos, Forsythia suspensa, and Amomum tsao-ko [143]. SARS-CoV-2 leads to the downregulation of ACE2 upon binding to the receptor, thus disrupting normal regulation of the ACE-Ang II and ACE2-Ang-(1-7) axes, consequently inducing multiple organ damage. Astragalus, Panax ginseng, Dioscorea spp., and arecae semen, which are major components of traditional Chinese medicine preparations for COVID-19 pneumonia, have shown a regulatory effect on the renin-angiotensin-aldosterone system (RAAS) [144]. Quercetin and its derivatives have strong binding ability to ACE2 and IL-6R and have the potential to inhibit the cytokine storm by blocking SARSCoV-2 and IL-6 binding. In addition, licorice, ephedra, Bupleurum root, etc., also have different IL-6R binding abilities [145-147]. Saikoside A and saikoside D had good affinity with Mpro and ACE2 of SARS-CoV-2 [148]. The binding strengths of baicalein and SARS-CoV-2 Mpro are the same as those of lopinavir and remdesivir, and the bond to ACE2 is relatively stable [149]. Liquiritin apioside, iridin, liquiritin, forsythiaside, procyanidin B-5,3'-o-gallate and saikosaponin $C$ are latent active $R d R p$ inhibitors, and their flavonoid structures may be potential active groups that induce RdRp inhibition [150]. Aster pentapeptide A, ligustrazine, salvianolic acid B, etc., have potential inhibitory effects on SARS-COV-2 Mpro, while gingerol, gin- nol, ferulic acid, etc., have potential inhibitory effects on SARS-COV-2 PLpro [151]. Hypericin and baicalein can bind to SARS-CoV-2 NSP14 and interact with key amino acid residues in the active centre [152].

SARS-CoV Glycyrrhizin $[128,129]$ is capable of inhibiting the invasion and replication of SARS-CoV in vitro, and various derivatives [130] (such as the introduction of 2-acetamide-glucan amine into the glycyrrhizin chain) may account for increased anti-SARS-CoV activity along with enhanced cytotoxicity. Lycorine from Lycoris radiata and ZZ-1 [131, 132] may inhibit SARS-CoV replication. Polysaccharides and ethyl acetate extracts from Houttuynia cordata act on the body's immune system with anti-complement activity, among which afzerin and quercetin also have antipyretic effects [133]. Houttuynia cordata also promotes the inhibition of RdRp [134]. Lung injury caused by SARS-CoV is associated with inflammation due to cytokine storms and neutrophil infiltration. Thus, inhibiting cAMP-PDE, which plays a key role in the inflammatory response, may help prevent inflammation. Rhizoma phragmitis, Folium isatidis, honeysuckle, forsythia, perilla leaf, mint and Astragalus significantly inhibit cAMP-PDE activity [135]. Multiflorum and Rheum rhabarbarum, specifically its extract-derived component emodin, affect virus invasion [136]. Protease inhibitors of natural origin include 3CLpro inhibitors (such as quinone-methide triterpenes extracted from Tripterygium regelii [137], dieckol from Ecklonia cava [138], and extracts of Houttuynia cordata and Rheum rhabarbarum $[134,136]$ ) and PLpro inhibitors (such as diarylheptanoids from Alnus japonica [139], and phenolic phytochemicals from the seeds of Psoralea corylifolia [140]). Finally, chalcone 6 from Angelica keiskei and tanshinones from Salvia miltiorrhiza are capable of inhibiting both 3CLpro and PLpro [141, 142].

MERS-CoV Silvestrol [153], an inhibitor of eIF4A, can inhibit viral mRNA cap-dependent translation. In addition, research on MERS-CoV 3CLpro suggests that flavonoids such as herbacetin, isobavachalcone, quercetin 3- $\beta$-D-glucoside and helichrysetin [154] can act as inhibitors.

HCoV-229E 3ß-Friedelanol [155], a triterpenoid extracted from the leaves of Euphorbia neriifolia, showed stronger antiviral activity than actinomycin $\mathrm{D}$, the positive control. Furthermore, silvestrol [153], an eIF4A inhibitor, affects the translation of $\mathrm{HCoV}-229 \mathrm{E}$.

HCoV-NL63 Caffeic acid, which is related to the ethanol extract of Sambucus FormosanaNakai [156], has been confirmed to have a significant inhibitory effect on the 
invasion of $\mathrm{HCoV}-\mathrm{NL63}$, possibly by directly interfering with the binding of HCoV-NL63 to ACE2 and co-receptors, such as heparin sulphate proteoglycan.

\section{Compound traditional Chinese medicines}

SARS-CoV-2 Based on the Chinese COVID-19 diagnosis and treatment scheme, ageratum upright capsules (in the form of pills, water, or oral liquid), Jinhuaqinggan particles, Lianhuaqingwen capsules (particles) and Shufengjiedu capsules (particles) are recommended during the SARS-CoV-2 medical observation period, while Qingfeipaidu soup (including Maxingshigan soup, Sheganmahuang soup, Xiaochaihu soup, Wuling powder), Xiyanping injection, Xuebijing injection, Reduning injection, Tanreqing injection, Xingnaojing injection, Shenfu injection, Shengmai injection and Shenmai injection are recommended in the clinical phase [99].

SARS-CoV The Ministry of Science and Technology of China has announced eight Chinese medicines that have been clinically confirmed to improve symptoms in SARS patients: Qingkailing injection, Houttuynia cordata injection, Radix isatidis granules, Xinxue granules, Jinlian Qingre granules, Dengzhanxixin injection, compound Kuh-seng injection and Xiangdan injection. In addition, Qingqi Liangying oral liquid and Qingwen oral liquid, and Jiedu pills, as well as anti-SARS I and anti-SARS II showed effective inhibitory effects on SARS-CoV [157] (Table 3).

\section{Discussion}

As of November 13, 2020, SARS-CoV-2 had infected 53218786 people worldwide and killed a total of 1301 631 people. Unfortunately, the epidemic is still not under control in many countries. Despite a lack of HCoV-specific drugs, many potent targets for drug discovery have been explored, and many vigorously designed clinical trials are being carried out in an orderly manner. In the present study, we analysed the pathogenesis of and drug therapy targeting seven $\mathrm{HCoVs}$, including four common types (HCoV-229E, -OC43, -NL63, -HKU1) and three highly pathogenic types (SARS-CoV, MERS-CoV, SARS$\mathrm{CoV}-2$ ); special attention was given to SARS-CoV-2.

Among the highly pathogenic CoVs, SARS-CoV transmission has been rare since 2004, so clinical trials of drugs and vaccines are difficult to carry out. To date, there are no specific drugs or vaccines against MERSCoV. mABs, such as m336 [9], lopinavir/ritonavir [30], IFN $[98,99]$, etc., are potential antiviral drugs against MERS-CoV, but additional evidence is needed to determine their efficacy.

Because COVID-19 is a new, acute, severe infectious disease, the anti-SARS-CoV-2 drug development strategies are to screen existing drugs to identify potentially effective drugs, to expand indications and to develop a vaccine. The safety of conventional drugs has been mostly verified; if effective, they can be quickly applied in clinical practice. To date, thousands of clinical trials of SARS-CoV-2 have been registered worldwide. Hot topics include antiviral drugs such as RaRp inhibitors [51-54, 59], Mpro inhibitors [48, 49], chloroquine and its derivatives [33, 34], viral envelope inhibitors, arbidol [27, 29], and immunotherapy drugs such as IFNs [100] and cytokine storm inhibitors [122, 123, 125-127]. Usually, the duration from initial experimental research to clinical trial completion is long. However, due to the COVID-19 pandemic, many drugs have been entered into clinical trials that are not randomized, controlled, or double-blinded. Their efficacy, toxicity, and side effects are discovered during application. For example, it was previously reported that hydroxychloroquine and chloroquine acted against coronavirus, and the synergistic use of hydroxychloroquine and azithromycin reduced the viral load and improved clinical results. However, later studies found that the heart-related side effects of these drugs included extension of the QT interval, so the WHO terminated the studies [33, 34]. Clinical trials found that lopinavir/ritonavir had a poor effect on COVID-19, while others, such as arbidol [27, 29], remdesivir [51-54], favipiravir [59], IFN- $\alpha 2 b$ [100], convalescent plasma [119, $120]$, corticosteroids $[122,123]$ and tocilizumab [125127], had different and even opposite results, which can be further validated by experimental evaluation and clinical experience. When the production of inflammatory factors is increased, convalescent plasma, corticosteroids, and tocilizumab should be used early and in appropriate amounts. Because most traditional Chinese medicines are compounds and few single drugs or single active ingredients are used, it is difficult to determine which ingredients are effective in clinical trials. It is hard to differentiate the compounds associated with the mechanism. In a laboratory study of a single active ingredient, glycyrrhizin had a strong inhibitory effect on SARS-CoV-2 [128, 129], which is of great significance for further clinical study. The future research direction for traditional Chinese medicine is to identify and modify a single potent drug or active ingredient and adjust the compound dose and administration method.

This review summarized the conventional and potential drugs at according to each action site, which can improve clinicians' understanding of the results of current clinical studies to guide clinical decisions. It also enables researchers to understand drug action sites to discover potential effective drugs. 


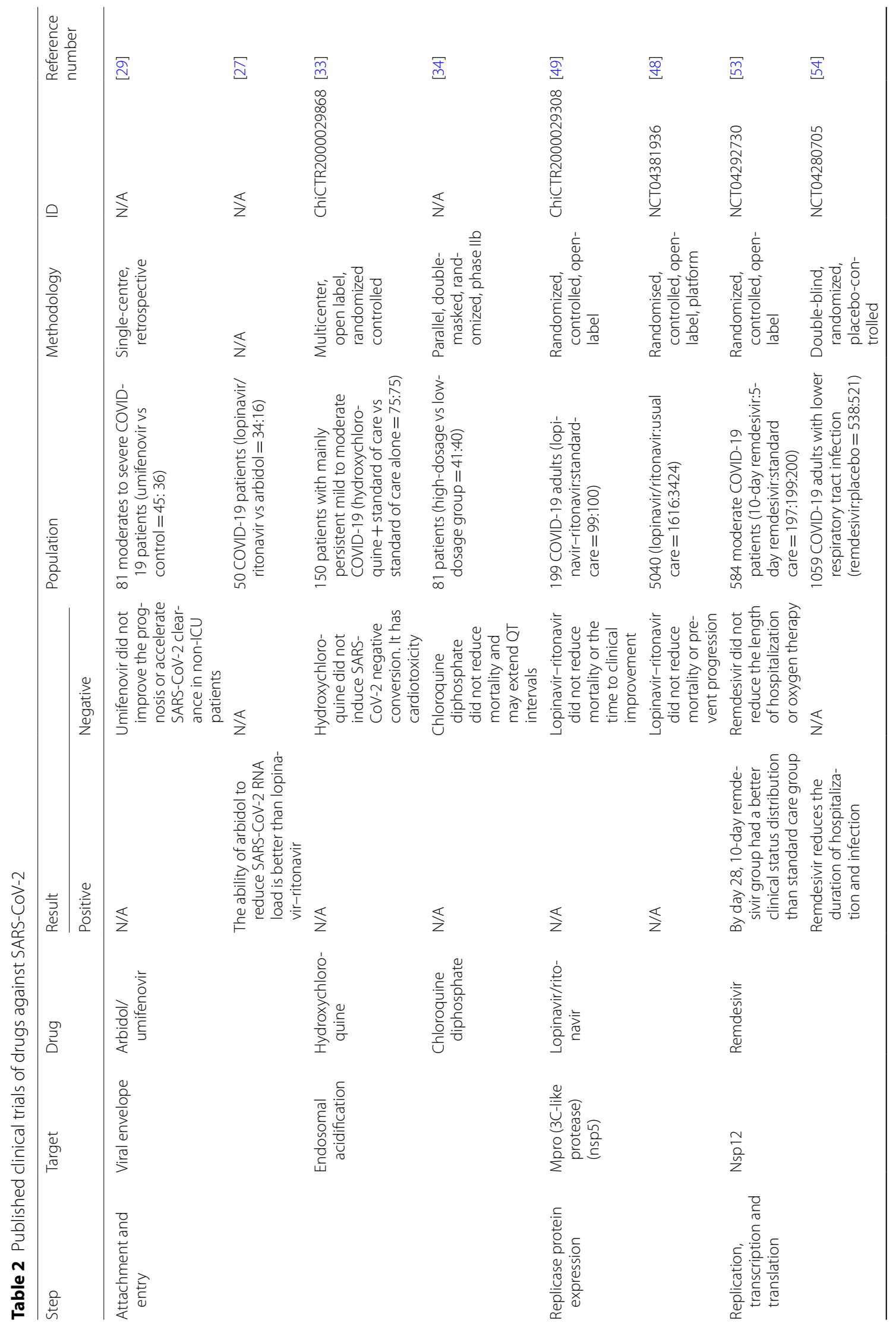




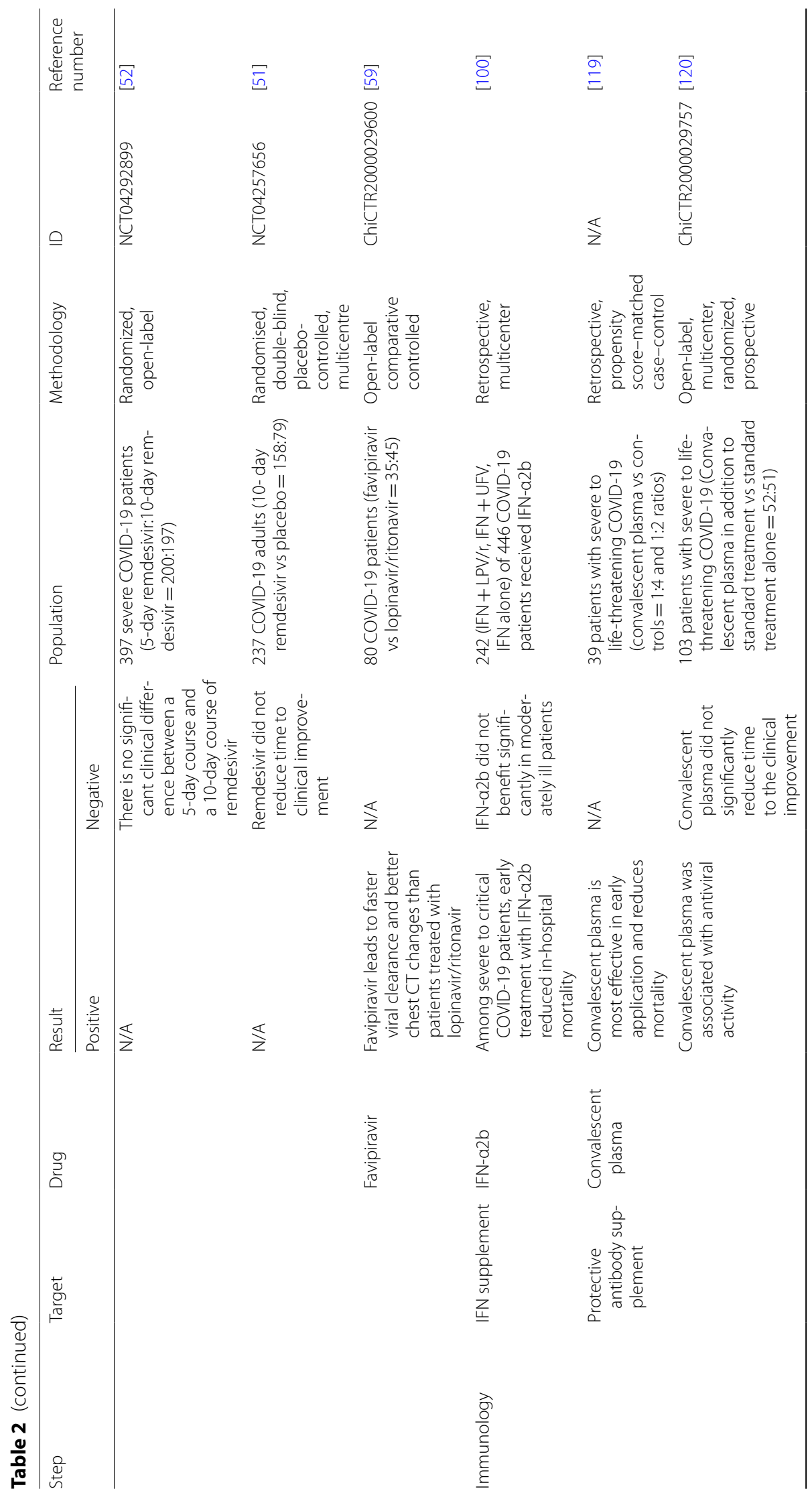




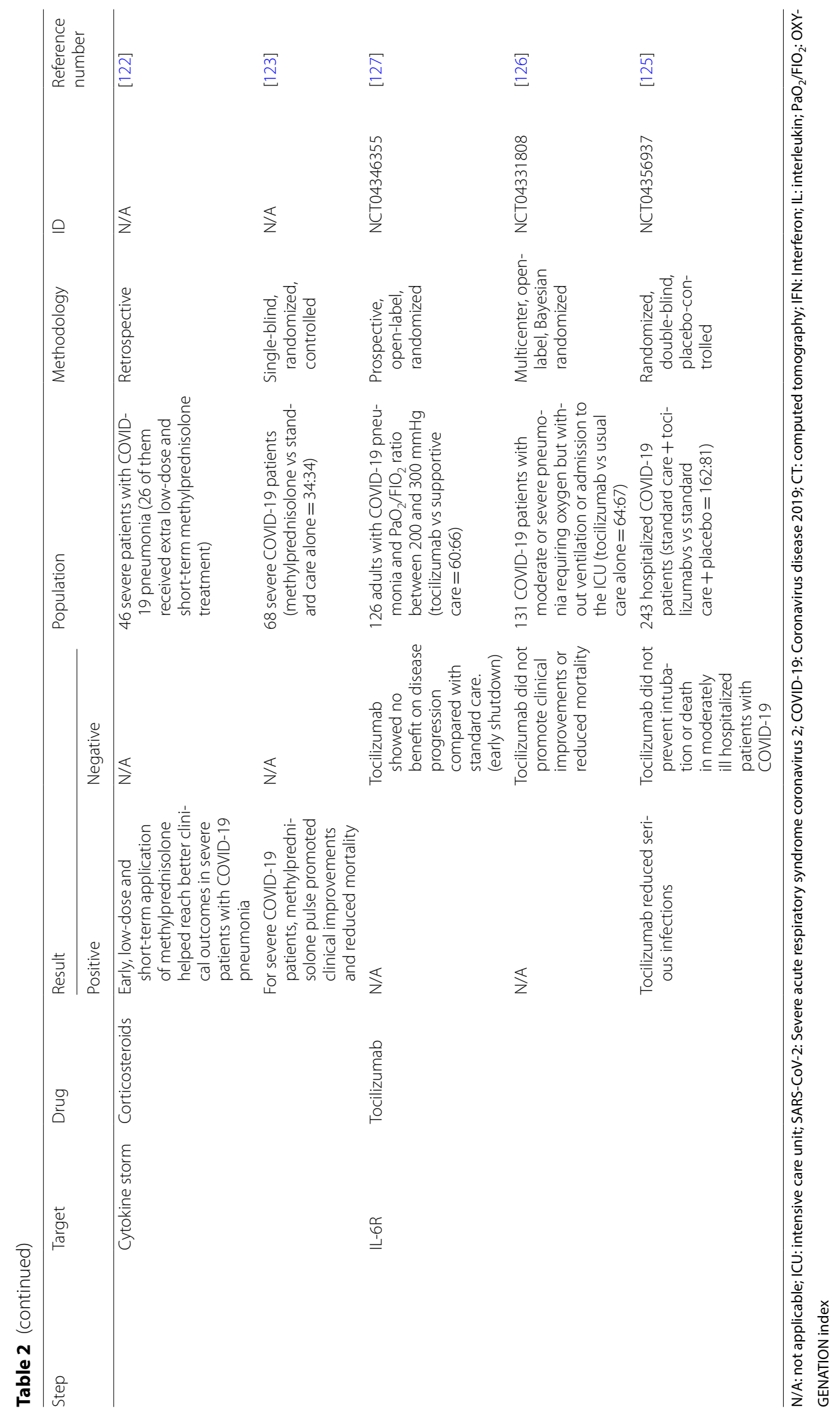




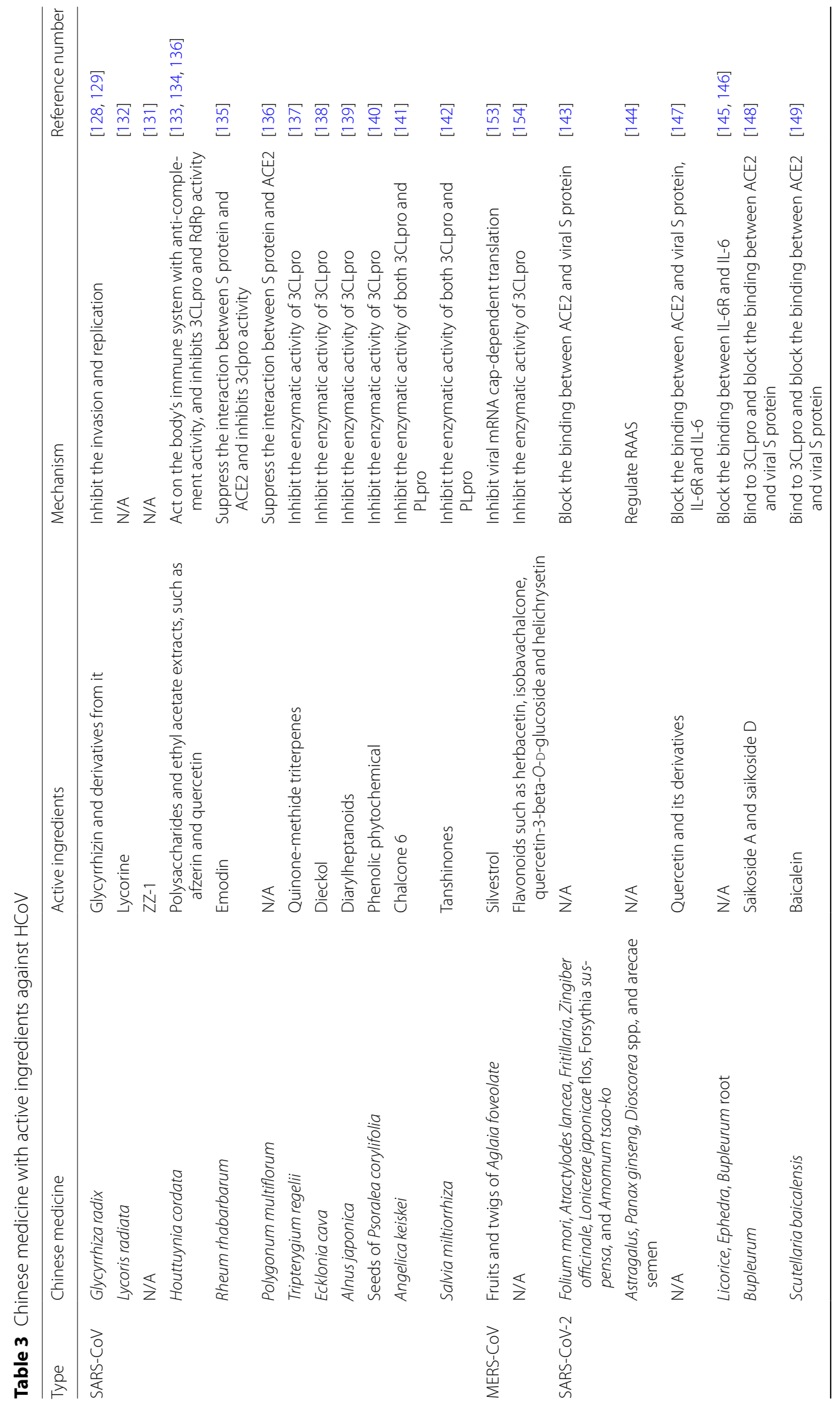




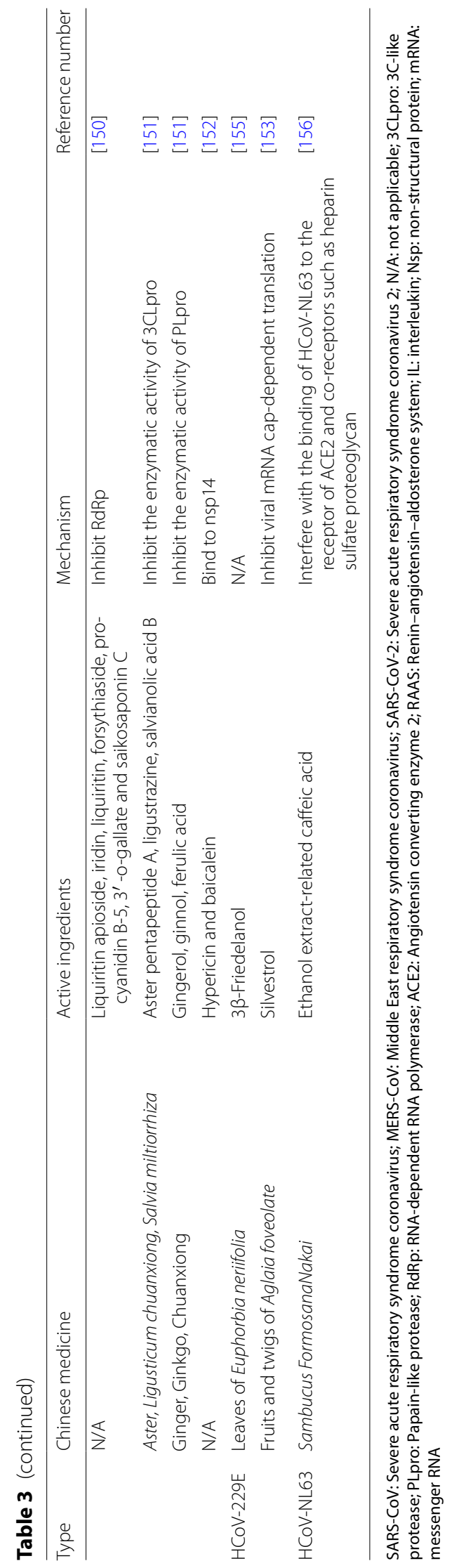




\section{Conclusions}

This review summarized the progress in drugs that inhibit the $\mathrm{HCoV}$ proliferation, affect the action of the host's immune system as well as plant-derived Chinese medicines, which not only provides researchers a more comprehensive understanding of the current status of drug development against $\mathrm{HCoVs}$, but also provides directions for further exploration. However, the pharmacological effects and adverse reactions of some drugs under study are still unclear, and hence well-designed high-quality studies are needed to further study the effectiveness and safety of these potential drugs in order to accelerate drug development targeting SARS-CoV-2 and thus promote progress towards ending the pandemic.

\section{Abbreviations}

CoV: Coronavirus; HCoVs: Human coronaviruses; SARS: Severe acute respiratory syndrome; MERS: Middle East respiratory syndrome; SARS-CoV-2: Severe acute respiratory syndrome coronavirus 2; SARS-CoV: Severe acute respiratory syndrome coronavirus; MERS-CoV: Middle East respiratory syndrome coronavirus; COVID-19: Coronavirus disease 2019; ARDS: Acute respiratory distress syndrome; IFNs: Interferons; gRNA: Genomic RNA; NSPs: Non-structural proteins; PLpro: Papain-like protease; Mpro: 3C-like protease; RdRp: RNA-dependent RNA polymerase; sgRNA: Subgenomic RNA; ERGIC: ER-Golgi intermediate compartment; RBD: Receptor binding domain; mABs: Monoclonal antibodies; NAAE: N-(2-Aminoethyl)-1-aziridineethanamine; DPP4: Dipeptidyl peptidase 4; GRFT: Griffithsin; TMPRSS2: Transmembrane protease serine 2; HR1: Heptad repeat 1 domain; HR2: Heptad repeat 2 domain; NHR: N-terminal heptad repeat; 6MP: 6-Mercaptopurine; 6TG: 6-Thioguanine; POMs: Polyoxometalates; PTB: Pyrithiobac; WHO: World Health Organization; TRS: Transcriptional regulatory sequence; mRNA: Messenger RNA; NTP: Nucleoside triphosphate; dsRNA: Double-stranded RNA; ADK: Aryl diketoacids; SAM: S-adenosyl-L-methionine; ATA: Aurintricarboxylic acid; siRNA: Small interfering RNAs; DMV: Doublemembrane vesicles; DRACO: DsRNA-activated caspase oligomerizer; TGEV: Transmissible gastroenteritis virus; ACE2: Angiotensin converting enzyme 2; RAAS: Renin-angiotensin-aldosterone system.
\end{abstract}

\section{Acknowledgements}

We thank Dr. Bo Cui for editing and helpful advice.

\section{Authors' contributions}

L-GS, Q-XX and H-LL were responsible for study selection and data extraction and drafted the manuscript. L-GS and Z-YL designed the study and revised the manuscript. All authors read and approved the final manuscript.

\section{Funding}

This work was supported by Grants from the Major Science and Technology Program of Hainan Province (Grant No. ZDKJ202003), the National Natural Science Foundation of China (Grant Nos. 81572023 and 81371836), the Guangdong Natural Science Foundation (Grant No. 2019A1515011541), the Science and Technology Planning Project of Guangdong Province (Grant No. 2019B030316025), the National Parasitic Resources Center of China (Grant No. NPRC-2019-194-30), the Open Foundation of Key Laboratory of Tropical Translational Medicine of the Ministry of Education, Hainan Medical University (Grant No. 2020TTM007), the 111 Project (Grant No. B12003), and the Teaching Reform Project of Guangdong Province (Grant No. 2017001).

\section{Availability of data and materials}

Not applicable.

\section{Declarations}

Ethics approval and consent to participate Not applicable.

\section{Consent for publication}

Not applicable.

\section{Competing interests}

The authors declare that they have no competing interests.

\section{Author details}

${ }^{1}$ The Eighth Affiliated Hospital, Sun Yat-Sen University, Shenzhen, Guangdong, China. ${ }^{2}$ Zhongshan School of Medicine, Sun Yat-Sen University, Guangzhou, Guangdong, China. ${ }^{3}$ NHC Key Laboratory of Control of Tropical Diseases, the First Affiliated Hospital, Hainan Medical University, Haikou, China. ${ }^{4}$ Key Laboratory of Tropical Disease Control (Sun Yat-Sen University), Ministry of Education, Guangzhou, China.

Received: 7 September 2020 Accepted: 25 February 2021

Published online: 16 March 2021

\section{References}

1. Zumla A, Chan JF, Azhar El, Hui DS, Yuen KY. Coronaviruses-drug discovery and therapeutic options. Nat Rev Drug Discov. 2016;15:327-47.

2. Maier HJ, Bickerton E, Editors PB. Coronaviruses: methods and orotocols. New York: Springer; 2015

3. Fung TS, Liu DX. Human coronavirus: Host-pathogen interaction. Annu Rev Microbiol. 2019;73:529-57.

4. Su S, Wong G, Shi W, Liu J, Lai ACK, Zhou J, et al. Epidemiology, genetic recombination, and pathogenesis of coronaviruses. Trends Microbiol. 2016;24:490-502.

5. WHO Coronavirus Disease (COVID-19) dashboard. https://covid19.who. int/. Accessed 2 June 2020.

6. Zhou F, Yu T, Du R, Fan G, Liu Y, Liu Z, et al. Clinical course and risk factors for mortality of adult inpatients with COVID-19 in Wuhan, China: a retrospective cohort study. Lancet. 2020;395:1054-62.

7. Zumla A, Chan JFW, Azhar El, Hui DSC, Yuen K. Coronaviruse-drug discovery and therapeutic options. Nat Rev Drug Discov. 2016;15:327-47.

8. Wang Huan DSAL. Advances in the study of coronavirus entry pathways. J Virol. 2019;06:964-71.

9. Ying T, Du L, Ju TW, Prabakaran P, Lau CC, Lu L, et al. Exceptionally potent neutralization of Middle East respiratory syndrome coronavirus by human monoclonal antibodies. J Virol. 2014;88:7796-805.

10. ter Meulen J, Bakker AB, van den Brink EN, Weverling GJ, Martina BE, Haagmans BL, et al. Human monoclonal antibody as prophylaxis for SARS coronavirus infection in ferrets. Lancet. 2004;363:2139-41.

11. Roberts A, Thomas WD, Guarner J, Lamirande EW, Babcock GJ, Greenough $\mathrm{TC}$, et al. Therapy with a severe acute respiratory syndrome-associated coronavirus-neutralizing human monoclonal antibody reduces disease severity and viral burden in golden Syrian hamsters. J Infect Dis. 2006;193:685-92.

12. Han DP, Penn-Nicholson A, Cho MW. Identification of critical determinants on ACE2 for SARS-CoV entry and development of a potent entry inhibitor. Virology. 2006;350:15-25.

13. Huentelman MJ, Zubcevic J, Hernandez PJ, Xiao X, Dimitrov DS, Raizada MK, et al. Structure-based discovery of a novel angiotensin-converting enzyme 2 inhibitor. Hypertension. 2004;44:903-6.

14. Ohnuma K, Haagmans BL, Hatano R, Raj VS, Mou H, Iwata S, et al. Inhibition of Middle East respiratory syndrome coronavirus infection by anti-CD26 monoclonal antibody. J Virol. 2013;87:13892-9.

15. Raj VS, Smits SL, Provacia LB, van den Brand JM, Wiersma L, Ouwendijk WJD, et al. Adenosine deaminase acts as a natural antagonist for dipeptidyl peptidase 4-mediated entry of the Middle East respiratory syndrome coronavirus. J Virol. 2014;88:1834-8.

16. O'Keefe BR, Giomarelli B, Barnard DL, Shenoy SR, Chan PK, McMahon JB, et al. Broad-spectrum in vitro activity and in vivo efficacy of the antiviral protein griffithsin against emerging viruses of the family Coronaviridae. JVirol. 2010;84:2511-21

17. Zhou Y, Vedantham P, Lu K, Agudelo J, Carrion RJ, Nunneley JW, et al. Protease inhibitors targeting coronavirus and filovirus entry. Antivir Res. 2015;116:76-84.

18. Yamamoto M, Matsuyama S, Li X, Takeda M, Kawaguchi Y, Inoue J, et al. Identification of nafamostat as a potent inhibitor of Middle East 
respiratory syndrome coronavirus S protein-mediated membrane fusion using the split-protein-based cell-cell fusion assay. Antimicrob Agents Chemother. 2016;60:6532-9.

19. Zhang H, Liu C, Li Q, Zhang J, Zhang X, Bai C, et al. Glycopeptide antibiotics potently inhibit cathepsin $\mathrm{L}$ in the late endosome/lysosome and block the entry of Ebola virus, Middle East respiratory syndrome coronavirus (MERS-CoV), and severe acute respiratory syndrome coronavirus (SARS-CoV). J Biol Chem. 2016;291:9218-32.

20. Gao J, Lu G, Qi J, Li Y, Wu Y, Deng Y, et al. Structure of the fusion core and inhibition of fusion by a heptad repeat peptide derived from the $S$ protein of Middle East respiratory syndrome coronavirus. J Virol. 2013:87:13134-40.

21. Channappanavar R, Lu L, Xia S, Du L, Meyerholz DK, Perlman S, et al. Protective effect of intranasal regimens containing peptidic Middle East respiratory syndrome coronavirus fusion inhibitor against MERS-CoV infection. J Infect Dis. 2015;212:1894-903.

22. Xia S, Xu W, Wang Q, Wang C, Hua C, Li W, et al. Peptide-based membrane fusion inhibitors targeting HCoV-229E spike protein HR1 and HR2 domains. Int J Mol Sci. 2018;19:487

23. Xia S, Yan L, Xu W, Agrawal AS, Algaissi A, Tseng CK, et al. A pan-coronavirus fusion inhibitor targeting the HR1 domain of human coronavirus spike. Sci Adv. 2019;5:v4580.

24. Blaising J, Polyak SJ, Pecheur E. Arbidol as a broad-spectrum antiviral: an update. Antivir Res. 2014;107:84-94.

25. Fontanes V, Moscona A, Hong PW, Grock A, Zhang TH, et al. A broadspectrum antiviral targeting entry of enveloped viruses. Proc Natl Acad Sci USA. 2010;107:3157-62.

26. Wang C, Zhao L, Xia S, Zhang T, Cao R, Liang G, et al. De novo design of alpha-helical lipopeptides targeting viral fusion proteins: a promising strategy for relatively broad-spectrum antiviral drug discovery. J Med Chem. 2018;61:8734-45.

27. Zhu Z, Lu Z, Xu T, Chen C, Yang G, Zha T, et al. Arbidol monotherapy is superior to lopinavir/ritonavir in treating COVID-19. J Infect. 2020;81:e21-3.

28. Huang D, Yu H, Wang T, Yang $H$, Yao R, Liang Z. Efficacy and safety of umifenovir for coronavirus disease 2019 (COVID-19): a systematic review and meta-analysis. J Med Virol. 2020. https://doi.org/10.1002/ jmv.26256.

29. Lian N, Xie H, Lin S, Huang J, Zhao J, Lin Q. Umifenovir treatment is not associated with improved outcomes in patients with coronavirus disease 2019: a retrospective study. Clin Microbiol Infect. 2020;26:917-21.

30. de Wilde AH, Jochmans D, Posthuma CC, Zevenhoven-Dobbe JC, van Nieuwkoop S, Bastebroer TM, et al. Screening of an FDA-approved compound library identifies four small-molecule inhibitors of Middle East respiratory syndrome coronavirus replication in cell culture. Antimicrob Agents Chemother. 2014;58:4875-84.

31. Schrezenmeier E, Dörner T. Mechanisms of action of hydroxychloroquine and chloroquine: implications for rheumatology. Nat Rev Rheumatol. 2020;16:155-66.

32. Yao X, Cui C, Liu D, Li H. Clinical pharmacology progress of chloroquine in the treatment of corona virus disease 2019. Clin Med J. 2020;02:30-3 (in Chinese).

33. Tang W, Cao Z, Han M, Wang Z, Chen J, Sun W, et al. Hydroxychloroquine in patients with mainly mild to moderate coronavirus disease 2019: open label, randomised controlled trial. BMJ. 2020;369:m1849.

34. Borba M, Val F, Sampaio VS, Alexandre M, Melo GC, Brito M, et al. Effect of high vs low doses of chloroquine diphosphate as adjunctive therapy for patients hospitalized with severe acute respiratory syndrome coronavirus 2 (SARS-CoV-2) infection: a randomized clinical trial. JAMA Netw Open. 2020;3:e208857.

35. Cheng K, Cheng S, Chen W, Lin M, Chuang S, Cheng I, et al. Thiopurine analogs and mycophenolic acid synergistically inhibit the papain-like protease of Middle East respiratory syndrome coronavirus. Antivir Res. 2015;115:9-16.

36. Cheng S, Moses DC, Sun C, Lin M, Hsieh C, Chen Y, et al. Disulfiram can inhibit MERS and SARS coronavirus papain-like proteases via different modes. Antivir Res. 2018;150:155-63.

37. Baez-Santos YM, St JS, Mesecar AD. The SARS-coronavirus papain-like protease: structure, function and inhibition by designed antiviral compounds. Antivir Res. 2015;115:21-38.
38. Clasman JR, Baez-Santos YM, Mettelman RC, O'Brien A, Baker SC, Mesecar AD, et al. X-ray structure and enzymatic activity profile of a core papain-like protease of MERS coronavirus with utility for structurebased drug design. Sci Rep. 2017;7:40292.

39. Kumar V, Shin JS, Shie JJ, Ku KB, Kim C, Go Y, et al. Identification and evaluation of potent Middle East respiratory syndrome coronavirus (MERS-CoV) 3CL(Pro) inhibitors. Antivir Res. 2017;141:101-6.

40. Karypidou K, Ribone SR, Quevedo MA, Persoons L, Pannecouque C, Helsen C, et al. Synthesis, biological evaluation and molecular modeling of a novel series of fused 1,2,3-triazoles as potential anti-coronavirus agents. Bioorg Med Chem Lett. 2018;28:3472-6.

41. Smolders EJ, Te BL, Burger DM. SARS-CoV-2 and HIV protease inhibitors: why lopinavir/ritonavir will not work for COVID-19 infection. Antivir Ther. 2020. https://doi.org/10.3851/IMP3365.

42. Hu D, Shao C, Guan W, Su Z, Sun J. Studies on the interactions of Ti-containing polyoxometalates (POMs) with SARS-CoV 3CL(pro) by molecular modeling. J Inorg Biochem. 2007;101:89-94.

43. Wu RJ, Zhou KX, Yang H, Song GQ, Li YH, Fu JX, et al. Chemical synthesis, crystal structure, versatile evaluation of their biological activities and molecular simulations of novel pyrithiobac derivatives. Eur J Med Chem. 2019;167:472-84.

44. Ren Z, Yan L, Zhang N, Guo Y, Yang C, Lou Z, et al. The newly emerged SARS-Like coronavirus HCoV-EMC also has an "Achilles' heel": current effective inhibitor targeting a 3 C-like protease. Protein Cell. 2013:4:248-50.

45. Chang K, Kankanamalage ACG, Fehr AR, Mehzabeen N, Battaile KP, Lovell S, et al. Structure-guided design of potent and permeable inhibitors of MERS coronavirus 3CL protease that utilize a piperidine moiety as a novel design element. Eur J Med Chem. 2018;150:334-46.

46. Konno H, Onuma T, Nitanai I, Wakabayashi M, Yano S, Teruya K, et al. Synthesis and evaluation of phenylisoserine derivatives for the SARSCoV 3CL protease inhibitor. Bioorg Med Chem Lett. 2017;27:2746-51.

47. Liu Y, Zheng TF, Jin F, Zhou L, Liu ZM, Wei P, et al. Design and bioassay of non-peptidic inhibitors of SARS coronavirus 3C-like proteinase. Acta Chim Sin. 2007:16:1707-12.

48. RECOVERY Collaborative Group. Lopinavir-ritonavir in patients admitted to hospital with COVID-19 (RECOVERY): a randomised, controlled, openlabel, platform trial. Lancet. 2020;396:1345-52.

49. Cao B, Wang Y, Wen D, Liu W, Wang J, Fan G, et al. A trial of lopinavirritonavir in adults hospitalized with severe COVID-19. N Engl J Med. 2020;19:1787-99.

50. Sheahan TP, Sims AC, Graham RL, Menachery VD, Gralinski LE, Case JB, et al. Broad-spectrum antiviral GS-5734 inhibits both epidemic and zoonotic coronaviruses. Sci Transl Med. 2017;9:eaal3653. https://doi. org/10.1126/scitranslmed.aal3653.

51. Wang Y, Zhang D, Du G, Du R, Zhao J, Jin Y, et al. Remdesivir in adults with severe COVID-19: a randomised, double-blind, placebo-controlled, multicentre trial. Lancet. 2020;395:1569-78.

52. Goldman JD, Lye D, Hui DS, Marks KM, Bruno R, Montejano R, et al. Remdesivir for 5 or 10 days in patients with severe COVID-19. N Engl J Med. 2020;383:1827-37.

53. Spinner CD, Gottlieb RL, Criner GJ, Arribas LJ, Cattelan AM, Viladomiu AS, et al. Effect of remdesivir vs standard care on clinical status at 11 days in patients with moderate COVID-19: a randomized clinical trial. JAMA. 2020;324:1048-57.

54. Beigel JH, Tomashek KM, Dodd LE. Remdesivir for the treatment of COVID-19-preliminary report. N Engl J Med. 2020;383:994.

55. Peters HL, Jochmans D, de Wilde AH, Posthuma CC, Snijder EJ, Neyts $J$, et al. Design, synthesis and evaluation of a series of acyclic fleximer nucleoside analogues with anti-coronavirus activity. Bioorg Med Chem Lett. 2015;25:2923-6.

56. Warren TK, Wells J, Panchal RG, Stuthman KS, Garza NL, Tongeren SAV, et al. Protection against filovirus diseases by a novel broad-spectrum nucleoside analogue BCX4430. Nature. 2014;508:402.

57. Yoon JS, Kim G, Jarhad DB, Kim HR, Shin YS, Qu S, et al. Design, synthesis, and anti-rna virus activity of 6'-fluorinated-aristeromycin analogues. J Med Chem. 2019;62:6346-62.

58. Shrestha DB, Budhathoki P, Khadka S, Shah PB, Pokharel N, Rashmi P. Favipiravir versus other antiviral or standard of care for COVID-19 treatment: a rapid systematic review and meta-analysis. Virol J. 2020;17:141. 
59. Cai Q, Yang M, Liu D, Chen J, Shu D, Xia J, et al. Experimental treatment with favipiravir for COVID-19: an open-label control study. Engineering (Beijing). 2020;6:1192-8.

60. Booth CM, Matukas LM, Tomlinson GA, Rachlis AR, Rose DB, Dwosh HA, et al. Clinical features and short-term outcomes of 144 patients with SARS in the greater Toronto area. JAMA. 2003;289:2801-9.

61. Adedeji AO, Singh K, Kassim A, Coleman CM, Elliott R, Weiss SR, et al. Evaluation of SSYA10-001 as a replication inhibitor of severe acute respiratory syndrome, mouse hepatitis, and Middle East respiratory syndrome coronaviruses. Antimicrob Agents Chemother. 2014;58:4894-8.

62. Lee C, Lee JM, Lee NR, Jin BS, Jang KJ, Kim DE, et al. Aryl diketoacids (ADK) selectively inhibit duplex DNA-unwinding activity of SARS coronavirus NTPase/helicase. Bioorg Med Chem Lett. 2009;19:1636-8.

63. Tanner JA, Zheng BJ, Zhou J, Watt RM, Jiang JQ, Wong KL, et al. The adamantane-derived bananins are potent inhibitors of the helicase activities and replication of SARS coronavirus. Chem Biol. 2005;12:303-11.

64. Kim MK, Yu MS, Park HR, Kim KB, Lee C, Cho SY, et al. 2,6-Bis-arylmethyloxy-5-hydroxychromones with antiviral activity against both hepatitis C virus (HCV) and SARS-associated coronavirus (SCV). Eur J Med Chem. 2011;46:5698-704.

65. Zaher NH, Mostafa MI, Altaher AY. Design, synthesis and molecular docking of novel triazole derivatives as potential CoV helicase inhibitors. Acta Pharm. 2020;70:145-59.

66. Menachery VD, Debbink K, Baric RS. Coronavirus non-structural protein 16: evasion, attenuation, and possible treatments. Virus Res. 2014;194:191-9.

67. Pfefferle S, Schopf J, Kogl M, Friedel CC, Muller MA, Carbajo-Lozoya $J$, et al. The SARS-coronavirus-host interactome: identification of cyclophilins as target for pan-coronavirus inhibitors. PLoS Pathog. 2011;7:e1002331.

68. de Wilde AH, Raj VS, Oudshoorn D, Bestebroer TM, van Nieuwkoop S, Limpens RWAL, et al. MERS-coronavirus replication induces severe in vitro cytopathology and is strongly inhibited by cyclosporin A or interferon-a treatment. J Gen Virol. 2013;94:1749-60.

69. Carbajo-Lozoya J, Ma-Lauer Y, Malešević M, Theuerkorn M, Kahlert $V$, Prell E, et al. Human coronavims NL63 replication is cyclophilin A-dependent and inhibited by non-immunosuppressive cyclosporine A-derivatives Including Alisporivir. Virus Res. 2014;184:44-53.

70. Dyall J, Coleman CM, Hart BJ, Venkataraman T, Holbrook MR, Kindrachuk J, et al. Repurposing of clinically developed drugs for treatment of Middle East respiratory syndrome coronavirus infection. Antimicrob Agents Chemother. 2014;58:4885-93.

71. Zhang Y, Li T, Fu L, Yu C, Li Y, Xu X, et al. Silencing SARS-CoV Spike protein expression in cultured cells by RNA interference. FEBS Lett. 2004;560:141-6.

72. Wu CJ, Huang HW, Liu CY, Hong CF, Chan YL. Inhibition of SARS-CoV replication by siRNA. Antivir Res. 2005;65:45-8.

73. He ML, Zheng BJ, Chen Y, Wong KL, Huang JD, Lin MC, et al. Development of interfering RNA agents to inhibit SARS-associated coronavirus infection and replication. Hong Kong Med J. 2009;15:28-31.

74. Nur SM, Hasan MA, Amin MA, Hossain M, Sharmin T. Design of potential RNAi (miRNA and siRNA) molecules for Middle East respiratory syndrome coronavirus (MERS-CoV) gene silencing by computational method. Interdiscip Sci. 2015;7:257-65.

75. Akerstrom S, Mirazimi A, Tan YJ. Inhibition of SARS-CoV replication cycle by small interference RNAs silencing specific SARS proteins, 7a/7b, 3a/3b and S. Antivir Res. 2007;73:219-27.

76. Tang Q, Li B, Woodle M, Lu PY. Application of siRNA against SARS in the rhesus macaque model. Methods Mol Biol. 2008:442:139-58.

77. Hart BJ, Dyall J, Postnikova E, Zhou H, Kindrachuk J, Johnson RF, et al. Interferon-beta and mycophenolic acid are potent inhibitors of Middle East respiratory syndrome coronavirus in cell-based assays. J Gen Virol. 2014;95:571-7.

78. Fukushima A, Fukuda N, Lai Y, Ueno T, Moriyama M, Taguchi F, et al. Development of a chimeric DNA-RNA hammerhead ribozyme targeting SARS virus. Intervirology. 2009;52:92-9.

79. Lundin A, Dijkman R, Bergstrom T, Kann N, Adamiak B, Hannoun C, et al. Targeting membrane-bound viral RNA synthesis reveals potent inhibition of diverse coronaviruses including the Middle East respiratory syndrome virus. PLoS Pathog. 2014;10:e1004166.
80. Rider TH, Zook CE, Boettcher TL, Wick ST, Pancoast JS, Zusman BD. Broad-spectrum antiviral therapeutics. PLOS ONE. 2011;6:e22572.

81. Lin SY, Liu CL, Chang YM, Zhao J, Perlman S, Hou MH. Structural basis for the identification of the $\mathrm{N}$-terminal domain of coronavirus nucleocapsid protein as an antiviral target. J Med Chem. 2014;57:2247-57.

82. Liao HI, Olson CA, Hwang S, Deng H, Wong E, Baric RS, et al. mRNA display design of fibronectin-based intrabodies that detect and inhibit severe acute respiratory syndrome coronavirus nucleocapsid protein. J Biol Chem. 2009;284:17512-20.

83. Lin SC, Ho CT, Chuo WH, Li S, Wang TT, Lin CC. Effective inhibition of MERS-CoV infection by resveratrol. BMC Infect Dis. 2017;17:144.

84. Wilson L, Gage P, Ewart G. Hexamethylene amiloride blocks E protein ion channels and inhibits coronavirus replication. Virology. 2006;353:294-306.

85. Ruediger A, Mayrhofer P, Ma-Lauer Y, Pohlentz G, Muething J, von Brunn $A$, et al. Tubulins interact with porcine and human $S$ proteins of the genus Alphacoronavirus and support successful assembly and release of infectious viral particles. Virology. 2016;497:185-97.

86. Jiang Y, Zhao G, Song N, Li P, Chen Y, Guo Y, et al. Blockade of the C5aC5aR axis alleviates lung damage in hDPP4-transgenic mice infected with MERS-CoV. Emerg Microbes Infect. 2018;7:77.

87. Sun S, Zhao G, Liu C, Wu X, Guo Y, Yu H, et al. Inhibition of complement activation alleviates acute lung injury induced by highly pathogenic avian influenza H5N1 virus infection. Am J Respir Cell Mol Biol. 2013;49:221-30.

88. Gralinski LE, Sheahan TP, Morrison TE, Menachery VD, Jensen K, Leist SR, et al. Complement activation contributes to severe acute respiratory syndrome coronavirus pathogenesis. mBio. 2018;9:e1718-53.

89. Kindler E, Thiel V, Weber F. Interaction of SARS and MERS coronaviruses with the antiviral interferon response. Adv Virus Res. 2016;96:219.

90. Mesel-Lemoine M, Millet J, Vidalain P, Law H, Vabret A, Lorin V, et al. A human coronavirus responsible for the common cold massively kills dendritic cells but not monocytes. J Virol. 2012;86:7577-87.

91. Siu K, Kok K, Ng MJ, Poon VKM, Yuen K, Zheng BJ, et al. Severe acute respiratory syndrome coronavirus $M$ protein inhibits type I interferon production by impeding the formation of TRAF3.TANK.TBK1/IKKepsilon complex. J Biol Chem. 2009;284:16202-9.

92. Yang $Y$, Zhang $L$, Geng $H$, Deng $Y$, Huang $B, G$ Go $Y$, et al. The structural and accessory proteins M, ORF 4a, ORF 4b, and ORF 5 of Middle East respiratory syndrome coronavirus (MERS-CoV) are potent interferon antagonists. Protein Cell. 2013:4:951-61.

93. Kopecky-Bromberg SA, Martínez-Sobrido L, Frieman M, Baric RA, Palese P. Severe acute respiratory syndrome coronavirus open reading frame (ORF) 3b, ORF 6, and nucleocapsid proteins function as interferon antagonists. J Virol. 2007;81:548-57.

94. Lokugamage KG, Narayanan K, Nakagawa K, Terasaki K, Ramirez SI, Tseng CT. Middle East respiratory syndrome coronavirus nsp1 inhibits host gene expression by selectively targeting mRNAs transcribed in the nucleus while sparing mRNAs of cytoplasmic origin. J Virol. 2015;89:10970-81.

95. Tanaka T, Kamitani W, DeDiego ML, Enjuanes L, Matsuura Y. Severe acute respiratory syndrome coronavirus nsp 1 facilitates efficient propagation in cells through a specific translational shutoff of host mRNA. J Virol. 2012;86:11128-37.

96. Yang $X$, Chen X, Bian G, Tu J, Xing Y, Wang Y, et al. Proteolytic processing, deubiquitinase and interferon antagonist activities of Middle East respiratory syndrome coronavirus papain-like protease. J Gen Virol. 2014;95:614-26.

97. Chinese Medical Association, China Association of Chinese Medicine. Consensus of the management of severe acute respiratory syndrome. Natl Med J Chin. 2003;83:1731-52 (in Chinese).

98. Channappanavar R, Fehr AR, Zheng J, Wohlford-Lenane C, Abrahante $J E$, Mack $M$, et al. IFN-I response timing relative to virus replication determines MERS coronavirus infection outcomes. J Clin Invest. 2019;130:3625-39.

99. Chinese Medical Association, China Association of Chinese Medicine. Guidelines on diagnosis and treatment of novel coronavirus pneumo nia (Trial sixth edition). Chin J Infect Contl. 2020;19:192-5 (in Chinese)

100. Wang N, Zhan Y, Zhu L, Hou Z, Liu F, Song P, et al. Retrospective multicenter cohort study shows early interferon therapy is associated with 
favorable clinical responses in COVID-19 patients. Cell Host Microbe. 2020;28:455-64.

101. Zhou J, Chu H, Chan JF, Yuen K. Middle East respiratory syndrome coronavirus infection: virus-host cell interactions and implications on pathogenesis. Virol J. 2015;12:218.

102. Guan W, Ni Z, Hu Y, Liang W, Ou C, He J, et al. Clinical characteristics of coronavirus disease 2019 in China. N Engl J Med. 2020;382(18):1708-20.

103. Zhao J, Li K, Wohlford-Lenane C, Agnihothram SS, Fett C, Zhao J, et al. Rapid generation of a mouse model for Middle East respiratory syndrome. Proc Natl Acad Sci USA. 2014;111:4970-5.

104. Liu WJ, Zhao M, Liu K, Xu K, Wong G, Tan W, et al. T-cell immunity of SARS-CoV: implications for vaccine development against MERS-CoV. Antivir Res. 2017;1:82-92.

105. Cameron MJ, Ran L, Xu L, Danesh A, Bermejo-Martin JF, Cameron CM, et al. Interferon-mediated immunopathological events are associated with atypical innate and adaptive immune responses in patients with severe acute respiratory syndrome. J Virol. 2007;81:8692-706.

106. Alshukairi AN, Khalid I, Ahmed WA, Dada AM, Bayumi DT, Malic LS, et al. Antibody response and disease severity in healthcare worker MERS survivors. Emerg Infect Dis. 2016;22:1113-5.

107. Tang F, Quan Y, Xin Z, Wrammert J, Ma M, Lv H, et al. Lack of peripheral memory $B$ cell responses in recovered patients with severe acute respiratory syndrome: a six-year follow-up study. J Immunol. 2011;186:7264-8.

108. ter Meulen J, van den Brink EN, Poon LLM, Marissen WE, Leung CSW, Cox F, et al. Human monoclonal antibody combination against SARS coronavirus: synergy and coverage of escape mutants. PLoS Med. 2006;3:e237.

109. Miyoshi-Akiyama T, Ishida I, Fukushi M, Yamaguchi K, Matsuoka Y, Ishihara T, et al. Fully human monoclonal antibody directed to proteolytic cleavage site in severe acute respiratory syndrome (SARS) coronavirus $S$ protein neutralizes the virus in a rhesus macaque SARS model. J Infect Dis. 2011:203:1574-81.

110. Houser KV, Gretebeck L, Ying T, Wang Y, Vogel L, Lamirande EW, et al. Prophylaxis with a Middle East respiratory syndrome coronavirus (MERS-CoV)—specific human monoclonal antibody protects rabbits from MERS-CoV infection. J Infect Dis. 2016;213:1557-61.

111. Pascal KE, Coleman CM, Mujica AO, Kamat V, Badithe A, Fairhurst J, et al. Pre- and postexposure efficacy of fully human antibodies against Spike protein in a novel humanized mouse model of MERS-CoV infection. Proc Natl Acad Sci USA. 2015;112:8738-43.

112. Johnson RF, Bagci U, Keith L, Tang X, Mollura DJ, Zeitlin L, et al. 3B11-N a monoclonal antibody against MERS-CoV, reduces lung pathology in rhesus monkeys following intratracheal inoculation of MERS-COV Jordan-n3/2012. Virology. 2016;490:49-58.

113. Corti D, Zhao J, Pedotti M, Simonelli L, Agnihothram S, Fett C, et al. Prophylactic and postexposure efficacy of a potent human monoclonal antibody against MERS coronavirus. Proc Natl Acad Sci USA. 2015;112:10473-8.

114. Chen Z, Bao L, Chen C, Zou T, Xue Y, Li F, et al. Human neutralizing monoclonal antibody inhibition of Middle East respiratory syndrome coronavirus replication in the common marmoset. J Infect Dis. 2017:215:1807-15.

115. Jiang L, Wang N, Zuo T, Shi X, Poon KM, Wu Y, et al. Potent neutralization of MERS-CoV by human neutralizing monoclonal antibodies to the viral spike glycoprotein. Sci Transl Med. 2014;6:234r-59r.

116. Niu P, Zhang S, Zhou P, Huang B, Deng Y, Qin K, et al. Ultrapotent human neutralizing antibody repertoires against Middle East respiratory syndrome coronavirus from a recovered patient. J Infect Dis. 2018;218:1249-60.

117. Tian X, Li C, Huang A, Xia S, Lu S, Shi Z, et al. Potent binding of 2019 novel coronavirus spike protein by a SARS coronavirus-specific human monoclonal antibody. Emerg Microbes Infect. 2020;9:382-5.

118. Mair-Jenkins J, Saavedra-Campos M, Baillie JK, Cleary P, Khaw F, Lim WS, et al. The effectiveness of convalescent plasma and hyperimmune immunoglobulin for the treatment of severe acute respiratory infections of viral etiology: a systematic review and exploratory meta-analysis. J Infect Dis. 2015;211:80-90.

119. Liu STH, Lin HM, Baine I, Wajnberg A, Gumprecht JP, Rahman F, et al. Convalescent plasma treatment of severe COVID-19: a propensity score-matched control study. Nat Med. 2020;26:1708-13.
120. Li L, Zhang W, Hu Y, Tong X, Zheng S, Yang J, et al. Effect of convalescent plasma therapy on time to clinical improvement in patients with severe and life-threatening COVID-19: a randomized clinical trial. JAMA. 2020;324:460-70.

121. Russell CD, Millar JE, Baillie JK. Clinical evidence does not support corticosteroid treatment for 2019-nCoV lung injury. Lancet. 2020;395:473-5.

122. Wang $Y$, Jiang $W$, He $Q$, Wang $C$, Wang $B$, Zhou $P$, et al. A retrospective cohort study of methylprednisolone therapy in severe patients with COVID-19 pneumonia. Signal Transduct Target Ther. 2020;5:57.

123. Edalatifard M, Akhtari M, Salehi M, Naderi Z, Jamshidi A, Mostafaei S, et al. Intravenous methylprednisolone pulse as a treatment for hospitalised severe COVID-19 patients: results from a randomised controlled clinical trial. Eur Respir J. 2020;56(6):2002808.

124. Sterne J, Murthy S, Diaz JV, Slutsky AS, Villar J, Angus DC, et al. Association between administration of systemic corticosteroids and mortality among critically ill patients with COVID-19: a meta-analysis. JAMA. 2020;324:1330-41.

125. Stone JH, Frigault MJ, Serling-Boyd NJ, Fernandes AD, Harvey L, Foulkes AS, et al. Efficacy of tocilizumab in patients hospitalized with COVID-19. N Engl J Med. 2020;383(24):2333-44

126. Hermine O, Mariette X, Tharaux PL, Resche-Rigon M, Porcher R, Ravaud $P$, et al. Effect of tocilizumab vs usual care in adults hospitalized with COVID-19 and moderate or severe pneumonia: a randomized clinical trial. JAMA Intern Med. 2020;20:e206820.

127. Salvarani C, Dolci G, Massari M, Merlo DF, Cavuto S, Savoldi L, et al. Effect of tocilizumab vs standard care on clinical worsening in patients hospitalized with COVID-19 pneumonia: a randomized clinical trial. JAMA Intern Med. 2021;181(1):24-31.

128. Cinatl J, Morgenstern B, Bauer G, Chandra P, Rabenau H, Doerr HW. Glycyrrhizin, an active component of liquorice roots, and replication of SARS-associated coronavirus. Lancet. 2003;361:2045-6.

129. Fiore C, Eisenhut M, Krausse R, Ragazzi E, Pellati D, Armanini D, et al. Antiviral effects of glycyrrhiza species. Phytother Res. 2008;22(2):141-8.

130. Hoever G, Baltina L, Michaelis M, Kondratenko R, Baltina L, Tolstikov GA, et al. Antiviral activity of glycyrrhizic acid derivatives against SARScoronavirus. J Med Chem. 2005;48(4):1256-9.

131. Wang M, Sun G, Wang X. Experimental study on effects of Chinese herbal preparations on SARS virus. Chin J Basic Med Tradit Chin Med. 2004;10:38-9 (in Chinese).

132. Li S, Chen C, Zhang H, Guo H, Wang H, Wang L, et al. Identification of natural compounds with antiviral activities against SARS-associated coronavirus. Antivir Res. 2005;67(1):18-23.

133. Lu Y, Jiang Y, Ling L, Zhang Y, Li H, Chen D. Beneficial effects of Houttuynia cordata polysaccharides on "two-hit" acute lung injury and endotoxic fever in rats associated with anti-complementary activities. Acta Pharm Sin B. 2018:8:218-27.

134. Lau K, Lee K, Koon C, Cheung CS, Lau C, Ho HM, et al. Immunomodulatory and anti-SARS activities of Houttuynia cordata. J Ethnopharmacol. 2008;118:79-85.

135. Jiang $D, C h e n ~ W, X u J, Y u T, L u P, M u X$. Effect of herbs for prevention and cure of SARS on neutrophil CAMP-phosphodiesterase activity. Chin J Vet Med. 2006;42:38-9 (in Chinese).

136. Kostoff RN. Literature-related discovery: Potential treatments and preventatives for SARS. Technol Forecast Soc Change. 2011;78:1164-73.

137. Ryu YB, Park SJ, Kim YM, Lee JY, Seo WD, Chang JS, et al. SARS-CoV $3 C L$ pro inhibitory effects of quinone-methide triterpenes from Tripterygium regelii. Bioorg Med Chem Lett. 2010;20:1873-6.

138. Park J, Kim JH, Kwon JM, Kwon H, Jeong HJ, Kim YM, et al. Dieckol, a SARS-CoV $3 \mathrm{CL}^{\text {pro }}$ inhibitor, isolated from the edible brown algae Ecklonia cava. Bioorg Med Chem. 2013;21:3730-7.

139. Park JY, Jeong HJ, Kim JH, Kim YM, Park SJ, Kim D, et al. Diarylheptanoids from Alnus japonica inhibit papain-like protease of severe acute respiratory syndrome coronavirus. Biol Pharm Bull. 2012;35:2036-42.

140. Kim DW, Seo KH, Curtis-Long MJ, Oh KY, Oh JW, Cho JK, et al. Phenolic phytochemical displaying SARS-CoV papain-like protease inhibition from the seeds of Psoralea corylifolia. J Enzyme Inhib Med Chem. 2014;29(1):59-63.

141. Park JY, Ko JA, Kim DW, Kim YM, Kwon HJ, et al. Chalcones isolated from Angelica keiskei inhibit cysteine proteases of SARS-CoV. J Enzyme Inhib Med Chem. 2016;31:23-30. 
142. Park JY, Kim JH, Kim YM, Jeong HJ, Kim DW, Jeong HJ, et al. Tanshinones as selective and slow-binding inhibitors for SARS-CoV cysteine proteases. Bioorg Med Chem. 2012;20:5928-35.

143. Niu M, Wang RL, Wang ZX, Zhang P, Bai ZF, Jing J, et al. Rapid establishment of traditional Chinese medicine prevention and treatment of 2019-nCoV based on clinical experience and molecular docking. Chin J Chin Materia Med. 2020;45:1213-8 (in Chinese).

144. Zhang Y, Tang D, Shu B, Li W, Zhang J, Li Y, et al. Evaluation and analysis on the SARS-CoV-2-induced injuries in multiple organs and the intervention of traditional Chinese medicine based on renin-angiotensin system. Modern Tradit Chin Med Materia Med-World Sci Tech. 2020;22:264-9 (in Chinese).

145. Jin X, Guan R, Mao J, Wang Y, Wang F, Li C, et al. Exploration on material basis of Qingfei Paidu Decoction with multi-target system against COVID-19 based on CADD. Chin Tradit Herb Drugs. 2020;51:1984-95 (in Chinese).

146. Zong Y, Yao W, Ju W. The intervention effect investigation of Chinese medicine monomer on cytokine storm induced by COVID-19 based on interleukin-6 receptor. Chin J Hosp Pharma. 2020;40:1182-8 (in Chinese).

147. Huang J, Zhang B, Lin Z. Intervention effect of Chinese medicine on interleukin cytokines and thinking on its prevention and treatment for inflammatory storm of COVID-19. Pharmacol Clin Chin Materia Med. 2020;36:23-8 (in Chinese).

148. Liu J, Fan M, Sun K, Sun R. Exploring active ingredients and function mechanism of Chaihu Guizhi Ganjiang Decoction against coronavirus disease 2019 based on molecular docking technology. Chin Tradit Herb Drugs. 2020;51:1704-12 (in Chinese).

149. Chen R, Wang T, Li K, Shang R, Song J, Zhang J. Characteristics and application of immune-regulating and antiviral Chinese materia medica. Chin Tradit Herb Drugs. 2020;51:1412-26 (in Chinese).
150. Li J, Wei B, Li K, Su X, Zhang Z. Natural product research and development. Nat Prod Res Dev. 2020;32:1981-91 (in Chinese).

151. Ma J, Huo X, Chen X, Zhu W, Yao M, Qian Y. Study on screening potential traditional Chinese medicines against 2019-nCoV based on Mpro and PLP. Chin J Chin Materia Med. 2020;1219-1224. (in Chinese).

152. Liu C, Zhu X, Lu Y, Zhang X, Jia X, Yang T. Potential treatment of Chinese and western medicine targeting Nsp14 of SARS-CoV-2. J Pharm Anal. 2020. https://doi.org/10.1016/j.jpha.2020.08.002.10.1016/j. jpha.2020.08.002.

153. Müller C, Schulte FW, Lange-Grünweller K, Obermann W, Madhugiri $\mathrm{R}$, Pleschka $\mathrm{S}$, et al. Broad-spectrum antiviral activity of the elF4A inhibitor silvestrol against corona- and picornaviruses. Antivir Res. 2018;150:123-9.

154. Jo S, Kim H, Kim S, Shin DH, Kim MS. Characteristics of flavonoids as potent MERS-CoV 3C-like protease inhibitors. Chem Biol Drug Des. 2019;94:2023-30.

155. Chang F, Yen C, Ei-Shazly M, Lin W, Yen M, Lin K, et al. Anti-human coronavirus (anti-HCoV) triterpenoids from the leaves of Euphorbia neriifolia. Nat Prod Commun. 2012;7:1415-7.

156. Wenga J, Linb C, Hsueh-Chou Laic D, Line Y, Wange C, Tsai YC, et al. Antiviral activity of Sambucus FormosanaNakai ethanol extract and related phenolic acid constituents against human coronavirus NL63. Virus Res. 2019;273:197767.

157. Liang A, Ling Y, Liu H. Application of traditional Chinese medicine in the prevention and treatment of SARS. Pharm J Chin People's Lib Army. 2003;19:367-9 (in Chinese).
Ready to submit your research? Choose BMC and benefit from:

- fast, convenient online submission

- thorough peer review by experienced researchers in your field

- rapid publication on acceptance

- support for research data, including large and complex data types

- gold Open Access which fosters wider collaboration and increased citations

- maximum visibility for your research: over 100M website views per year

At BMC, research is always in progress.

Learn more biomedcentral.com/submissions 